\title{
Comparison of CALIPSO aerosol optical depth retrievals to AERONET measurements, and a climatology for the lidar ratio of dust
}

\author{
G. L. Schuster ${ }^{1}$, M. Vaughan ${ }^{1}$, D. MacDonnell ${ }^{1}$, W. Su ${ }^{1}$, D. Winker ${ }^{1}$, O. Dubovik ${ }^{2}$, T. Lapyonok ${ }^{2}$, and C. Trepte ${ }^{1}$ \\ ${ }^{1}$ NASA Langley Research Center, Hampton, Virginia, USA \\ ${ }^{2}$ Laboratoire d'Optique Atmosphérique, Université de Lillé 1, CNRS, Villeneuve d'Ascq, France
}

Correspondence to: G. L. Schuster (gregory.1.schuster@nasa.gov)

Received: 13 April 2012 - Published in Atmos. Chem. Phys. Discuss.: 7 May 2012

Revised: 19 July 2012 - Accepted: 3 August 2012 - Published: 17 August 2012

\begin{abstract}
We compared CALIPSO column aerosol optical depths at $0.532 \mu \mathrm{m}$ to measurements at 147 AERONET sites, synchronized to within 30 min of satellite overpass times during a 3-yr period. We found 677 suitable overpasses, and a CALIPSO bias of $-13 \%$ relative to AERONET for the entire data set; the corresponding absolute bias is -0.029 , and the standard deviation of the mean (SDOM) is 0.014 . Consequently, the null hypothesis is rejected at the $97 \%$ confidence level, indicating a statistically significant difference between the datasets. However, if we omit CALIPSO columns that contain dust from our analysis, the relative and absolute biases are reduced to $-3 \%$ and -0.005 with a standard error of 0.016 for 449 overpasses, and the statistical confidence level for the null hypothesis rejection is reduced to $27 \%$. We also analyzed the results according to the six CALIPSO aerosol subtypes and found relative and absolute biases of $-29 \%$ and -0.1 for atmospheric columns that contain the dust subtype exclusively, but with a relatively high correlation coefficient of $R=0.58$; this indicates the possibility that the assumed lidar ratio ( $40 \mathrm{sr}$ ) for the CALIPSO dust retrievals is too low. Hence, we used the AERONET size distributions, refractive indices, percent spheres, and forward optics code for spheres and spheroids to compute a lidar ratio climatology for AERONET sites located in the dust belt. The highest lidar ratios of our analysis occur in the non-Sahel regions of Northern Africa, where the median lidar ratio at $0.532 \mu \mathrm{m}$ is $55.4 \mathrm{sr}$ for 229 retrievals. Lidar ratios are somewhat lower in the African Sahel ( $49.7 \mathrm{sr}$ for 929 retrievals), the Middle East (42.6 sr for 489 retrievals), and Kanpur, India (43.8 sr for 67 retrievals). We attribute this regional variability in the lidar
\end{abstract}

ratio to the regional variability of the real refractive index of dust, as these two parameters are highly anti-correlated (correlation coefficients range from -0.51 to -0.85 for the various regions). The AERONET refractive index variability is consistent with the variability of illite concentration in dust across the dust belt.

\section{Introduction}

Global profiling of aerosols and clouds is a unique feature of the Cloud-Aerosol Lidar and Infrared Pathfinder Satellite Observations (CALIPSO) mission (Winker et al., 2010). This is achieved through analysis of backscatter measurements provided by the Cloud-Aerosol Lidar with Orthogonal Polarization (CALIOP) instrument, which is located onboard the CALIPSO satellite of the NASA A-Train (Hunt et al., 2009; Winker et al., 2009). The CALIPSO product determines the locations of layers within the atmosphere (Vaughan et al., 2009), discriminates aerosol layers from clouds (Liu et al., 2009), categorizes aerosol layers as one of six subtypes (dust, marine, smoke, polluted dust, polluted continental, and clean continental; Omar et al., 2009), and estimates the optical depth of each layer detected (Young and Vaughan, 2009). The aerosol height information provided by the CALIOP extinction profiles is vital for validating source strengths and improving aerosol radiative forcing calculations in global aerosol models.

The accuracy of the extinction and optical depth retrievals depend upon the performance of several upstream processes, 
including instrument calibration, layer detection sensitivity, and accurate layer classification. The CALIOP $532 \mathrm{~nm}$ channel is known to be accurately calibrated (Rogers et al., 2011), and a number of previous studies have shown that the performance of the CALIPSO layer detection scheme is consistent with the predictions and limitations described in the project's algorithm theoretical basis document (Vaughan et al., 2005; McGill et al., 2007; Dupont et al., 2010; Thorsen et al., 2011; Yorks et al., 2011). Although there are few systematic studies of CALIOP's aerosol subtyping reported in the literature, the available comparisons suggest that the CALIOP scheme is successful $\sim 70 \%$ of the time; the best agreement occurs for dust, and the least agreement occurs for aerosol layers dominated by the fine mode (Mielonen et al., 2009).

One important element for determining aerosol optical depth from backscatter lidar signals is the lidar ratio (or extinction-to-backscatter ratio) assigned to each aerosol layer. Hence, significant effort has been expended on assessing the accuracy of the lidar ratios used for the various CALIOP aerosol subtypes. For example, Sayer et al. (2012) use sunphotometer measurements from selected locations within the Aerosol Robotic Network (AERONET) to derive lidar ratios for marine aerosols at $0.532 \mu \mathrm{m}$ and $1.064 \mu \mathrm{m}$, and obtained results that are substantially different from those used in the CALIOP subtyping model. Similarly, several analyses of lidar measurements observed with the European Aerosol Research Lidar Network (EARLINET) and during the Saharan Mineral Dust Experiment (SAMUM) suggest that the characteristic lidar ratio for the CALIOP dust model is also too low (e.g., Tesche et al., 2009; Pappalardo et al., 2010; Wandinger et al., 2010). In contrast, studies using in-situ measurements from the NASA African Monsoon Multidisciplinary Analyses (NAMMA) campaign tend to verify the correctness of the CALIOP dust model (Omar et al., 2010). Thus, continued research and analysis in this area is clearly desirable.

Validation studies that examine CALIOP estimates of aerosol optical depth (AOD) typically reveal a low bias in the CALIOP data relative to other measurements and retrievals. Kittaka et al. (2011) and Redemann et al. (2012) used different strategies to compare CALIOP total column AOD estimates to spatially and temporally matched AOD retrievals from measurements by the Moderate Resolution Imaging Spectroradiometer (MODIS) instrument onboard the Aqua satellite. Both studies observe that the CALIOP daytime AOD estimates are somewhat lower than the corresponding MODIS values, and both suggest ways to filter the data to obtain the most reliable set of CALIOP retrievals.

In this work, we extend and augment previous CALIOP AOD validation efforts by comparing the $0.532 \mu \mathrm{m}$ column AOD estimates from the CALIPSO version 3 data products to ground-based sunphotometer measurements obtained at multiple AERONET sites located around the globe. When these global AOD comparisons are decomposed according to the CALIOP aerosol type, we find that dust exerts a signif-
Table 1. Requirements for this CALIPSO and AERONET aerosol optical depth comparison.

1. CALIPSO Level 2, Version 3 cloud-free column aerosol optical depths at the closest approach

2. AERONET Level 2, Version 2 (includes cloud screening and quality control)

3. CALIPSO laser footprint collocated within $80 \mathrm{~km}$ of AERONET site

4. CALIPSO overpass synchronized to within $30 \mathrm{~min}$ of AERONET AOD measurement

5. CALIPSO DEM* surface elevation must be within $100 \mathrm{~m}$ of AERONET site elevation

6. CALIPSO extinction QC flag $=0$ for all layers

7. CALIPSO CAD score less than -20 for all layers

* DEM: digital elevation map.

icant influence on the quality of the comparisons. We therefore also use the AERONET sky-scan retrievals to compute a lidar ratio climatology for dust that can be compared to the standard CALIOP dust model to help assess the reasons for the observed AOD differences.

\section{Method}

We compare provisional CALIPSO column aerosol optical depth retrievals to aerosol robotics network (AERONET) measurements for approximately $3 \mathrm{yr}$ of data (13 June 200631 May 2009). Data products, cloud clearing, collocation, and synchronization requirements are outlined in this section, and summarized in Table 1.

\subsection{CALIPSO product}

We use the CALIPSO 5-km Aerosol Layer Product (Level 2, Version 3), which provides aerosol layer optical depths and total column optical depth at wavelengths of $0.532 \mu \mathrm{m}$ and $1.064 \mu \mathrm{m}$. For each aerosol layer detected, CALIPSO infers an aerosol subtype for that layer based upon surface type (land vs. water), layer integrated attenuated backscatter and depolarization ratio at $0.532 \mu \mathrm{m}$, and aerosol layer height (Omar et al., 2009). Layer extinction profiles and optical depths at both wavelengths are then determined using lidar ratios that characterize the aerosol subtypes (see the 2nd column of Table 2 for values). The aerosol layer subtypes in the Version 3 CALIPSO product include dust, polluted dust, clean continental, polluted continental, marine, and smoke.

The CALIPSO 5-km Aerosol Layer Product reports the spatial and optical properties of aerosol layers that were detected at horizontal averaging resolutions of 5, 20, and $80 \mathrm{~km}$, and vertical resolutions of up to $30 \mathrm{~m}$ (depending upon conditions and altitude; Vaughan et al., 2009; Young and Vaughan, 2009; Omar et al., 2009; Winker et al., 2009, 2010; Kittaka et al., 2011). These products are reported on a 
Table 2. Lidar ratios $\left(S_{\mathrm{a}}\right)$ at $532 \mathrm{~nm}$ and statistics for aerosol optical depth comparisons for different aerosol subtypes (as defined by CALIPSO). Maximum closest approach is $80 \mathrm{~km}$. Average AERONET aerosol optical depth $\left(\overline{\tau_{\mathrm{A}}}\right)$ at the $0.532 \mu \mathrm{m}$ wavelength, absolute bias and standard error $\left(B_{\mathrm{a}}, \sigma_{\mathrm{a}}\right)$, student's t-test score and $p$-value $(t, p)$, relative bias $\left(B_{\mathrm{r}}\right)$, root-mean-square error (RMS), correlation coefficient $(R)$, and number of comparisons $(N)$. Regions denoted with $(*)$ indicate absolute biases that exceed the $95 \%$ confidence interval of the means (i.e., t-score magnitudes greater than 2 and $p$-values less than 0.05).

\begin{tabular}{lrrrrrrrrrr}
\hline Subtype & $S_{\mathrm{a}}$ & $\overline{\tau_{\mathrm{A}}}$ & $B_{\mathrm{a}}$ & $\sigma_{\mathrm{a}}$ & $t$ & $p$ & $B_{\mathrm{r}}$ & $\mathrm{RMS}$ & $R$ & $N$ \\
\hline Polluted Dust & 65 & 0.175 & -0.023 & 0.022 & -1.049 & 0.295 & -0.132 & 0.174 & 0.671 & 157 \\
Dust* $^{*}$ & 40 & 0.324 & -0.095 & 0.033 & -2.898 & 0.004 & -0.292 & 0.270 & 0.575 & 142 \\
Polluted Cont & 70 & 0.163 & -0.029 & 0.017 & -1.662 & 0.099 & -0.176 & 0.141 & 0.198 & 80 \\
Marine* $_{\text {Smoke }}$ & 20 & 0.165 & -0.114 & 0.024 & -4.679 & 0.000 & -0.686 & 0.198 & 0.198 & 50 \\
Clean Cont $^{*}$ & 30 & 0.249 & 0.074 & 0.090 & 0.816 & 0.418 & 0.295 & 0.382 & 0.447 & 31 \\
\hline Total & 0.086 & -0.054 & 0.017 & -3.153 & 0.010 & -0.626 & 0.071 & -0.496 & 6 \\
\hline
\end{tabular}

uniform horizontal grid of $5 \mathrm{~km}$ so that the properties of an isolated layer detected with an $80-\mathrm{km}$ horizontal averaging resolution will be reported identically across 16 consecutive 5-km columns. The aerosol column optical depths reported in the CALIPSO data products is computed by integrating all of the aerosol extinction coefficients within each $5-\mathrm{km}$ horizontally-averaged column, irrespective of the averaging resolution required to detect the layers within the column.

It is important to note that CALIPSO only retrieves estimates of aerosol extinction where layers are detected. That is, the signal-to-noise ratios in "clear air" regions are often too low to permit accurate retrievals of extinction estimates on the standard CALIPSO averaging grid; this is especially problematic during the daytime measurements of our comparisons. As a consequence, highly diffuse and/or weakly scattering aerosols that lie below the CALIPSO detection threshold will be omitted from the CALIPSO estimates of column AOD.

\subsection{AERONET product}

We use the AERONET aerosol optical depth product (Level 2, Version 2). AERONET consists of more than 180 sun and sky scanning radiometers located at surface sites throughout the world (Holben et al., 1998). Unlike CALIPSO - which provides estimates of aerosol optical depth based on inferred aerosol type and composition - the AERONET sunphotometers directly measure aerosol optical depths at seven wavelengths (approximately 0.340, 0.380, $0.440,0.500,0.675,0.870$, and $1.02 \mu \mathrm{m}$ ) with an estimated uncertainty of $0.01-0.02$ (Holben et al., 2001). Unfortunately, AERONET does not provide aerosol optical depths at the CALIOP visible wavelength $(0.532 \mu \mathrm{m})$, so we use a 2 ndorder variation of the Angstrom relation to interpolate between all available AERONET wavelengths (Schuster et al., 2006):

$\ln \tau_{\mathrm{A}}(\lambda)=a_{0}+a_{1} \ln \lambda+a_{2}(\ln \lambda)^{2}$.
That is, the aerosol optical depths $\tau_{\mathrm{A}}(\lambda)$ provided by AERONET are used to determine the coefficients $a_{0}, a_{1}, a_{2}$ via a 2nd-order least-squares regression. These coefficients can then be used to accurately determine the aerosol optical depth at any wavelength $(\lambda)$ in the visible region.

\subsection{Cloud clearing and quality control}

The presence of clouds can confound our AOD comparison, especially if one instrument detects a cloud and the other one does not. The AERONET Level 2 product includes automatic cloud screening that utilizes tools such as 1-min stability tests, diurnal stability tests, smoothness tests, and qualityassurance inspections (Smirnov et al., 2000). We note, however, that recent comparisons between AERONET and collocated micro-pulse lidar network (MPLNET) measurements have shown that the AERONET cloud screening procedure often misses thin cirrus in Southeast Asia (Huang et al., 2011; Chew et al., 2011). The range of AOD bias associated with thin cirrus is estimated at $\sim 0.03-0.06$ in Singapore (Chew et al., 2011) and the monthly bias is estimated as $5 \%$ for Phimai, Thailand. The magnitude of this problem at AERONET sites in the rest of the world remains unquantified, however.

We also require the absence of clouds in the CALIPSO data columns that we use in our comparisons, and consider only quality-controlled aerosol products. That is, we require CALIPSO Extinction QC $532=0$, indicating that a successful extinction solution was achieved with the default lidar ratio assigned to each layer (although this affects only four overpasses). We require the CALIPSO cloud and aerosol detection score (CAD Score) to be less than -20 , which is consistent with the upcoming production rules for the CALIPSO Level 3 aerosol profile products. This avoids aerosol layers which might be the result of detection artifacts. CALIPSO also provides the USGS GTOPO30 digital elevation map (DEM) at the CALIOP footprint, and we require DEM surface elevations to be within $100 \mathrm{~m}$ of the AERONET sites in our analysis; this is critical for assuring equal optical path lengths for the CALIPSO and AERONET 


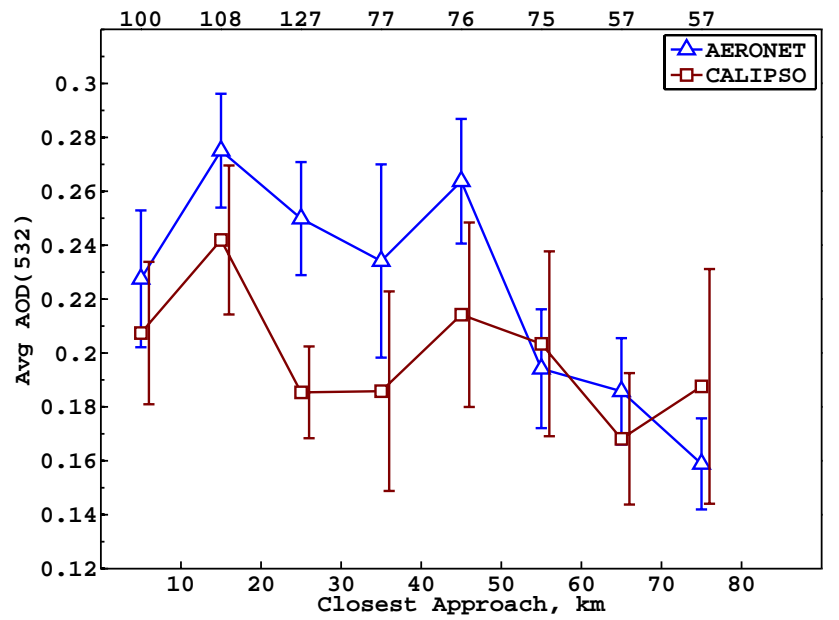

Fig. 1. Average AERONET and CALIPSO aerosol optical depths at the $0.532 \mu \mathrm{m}$ wavelength as a function of the CALIPSO closest approach, centered on 10-km wide bins. Upper abscissa indicates the corresponding number of overpasses, and errorbars indicate \pm one standard deviation of the mean. Note that the greatest divergence of the optical depths does not occur at the greatest overpass distances, indicating that the difference between the datasets is not dominated by spatial heterogeneity of the aerosol fields.

instruments. Finally, we do not screen for opaque aerosol layers in the CALIPSO product (no ground return), but there are no opaque layers in our analysis.

\subsection{Spatial collocation}

CALIPSO reports aerosol layer products as averages in nearvertical "sheets" along the satellite track; the AERONET field of view is a pencil beam from the solar disc to the instrument. One difficulty with this arrangement is that these instruments rarely sample the same part of the atmosphere. Hence, we must determine an acceptable "closest approach", which we define as the minimum horizontal overpass distance between the CALIPSO sheet and the AERONET instrument. Then we use data from $5-\mathrm{km}$ segments of the CALIPSO track that occur during the closest approach. (One drawback to this method is that the closest approach is not always the best location for CALIPSO comparisons because of small scale inhomogeneities, but the bias produced by using the closest approach is near zero; Omar et al., 2012.) We explore the possibility of using horizontal satellite overpass distances of up to $80 \mathrm{~km}$ in this section.

We bin the average $\tau(532)$ as a function of closest approach for both instruments at 147 AERONET sites, and present the results in Fig. 1. Here, the data are centered on $10-\mathrm{km}$ wide bins, the error bars represent one standard deviation of the mean, and the upper abscissa indicates the number of overpasses at each distance. Not surprisingly, Fig. 1 indicates that the two datasets show better agreement when the CALIPSO satellite passes within $10 \mathrm{~km}$ than when it

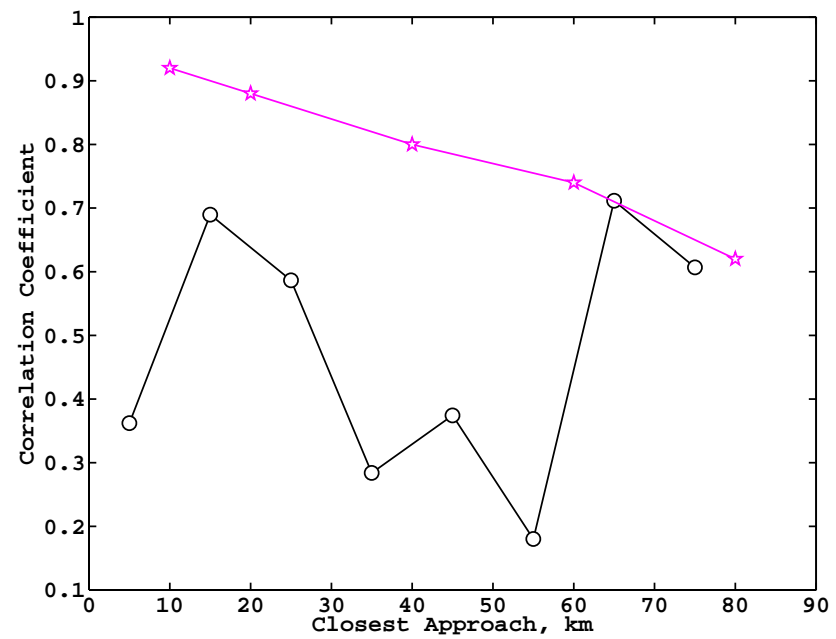

Fig. 2. Correlation coefficients for the optical depths of Fig. 1 (black circles) and the autocorrelations of aerosol plumes measured by Anderson et al. (2003). Correlations that are significantly less than the Anderson et al. (2003) values indicate that other factors are more important than spatial separation.

passes at distances of $10-50 \mathrm{~km}$. However, the comparison improves at even greater distances $(50-80 \mathrm{~km})$, indicating that other factors are more important than spatial separation at the largest separation distances.

This is corroborated by Fig. 2, which shows correlation coefficients for each distance bin presented in Fig. 1 (round symbols). Note that the correlations in Fig. 2 are not related to the satellite closest approach, and that the correlation at $5 \mathrm{~km}$ is worse than the correlation at most of the other overpass distances (i.e., the correlations at 35 and $55 \mathrm{~km}$ are the only correlations worse than the 5-km correlation).

Figure 2 also presents the autocorrelation of atmospheric aerosol plumes measured by Anderson et al. (2003) using data from the Lidar In-space Technology Experiment (LITE) as well as in situ measurements (stars). Note that Anderson et al. (2003) measured autocorrelations of 0.62-0.92 for separation distances of up to $80 \mathrm{~km}$, which is well above the correlation that we obtain at most separation distances. Hence, it is highly likely that something besides the natural autocorrelation of the aerosols is reducing the correlation of the CALIPSO/AERONET datasets below the Anderson et al. (2003) measured values, and also causing an increase in the bias.

Note, however, that each distance bin shown in Figs. 1 and 2 represents a unique set of AERONET sites that is not included in any of the other distance bins. That is, the AERONET sites used to compute the average values in the $5-\mathrm{km}$ bin are not the same sites as used in the $15-\mathrm{km}$ bin; this is because the fixed orbit pattern of the CALIPSO satellite tends to produce a characteristic "miss distance" for each site. Thus, sorting the data according to the satellite closest approach does not provide information about which 


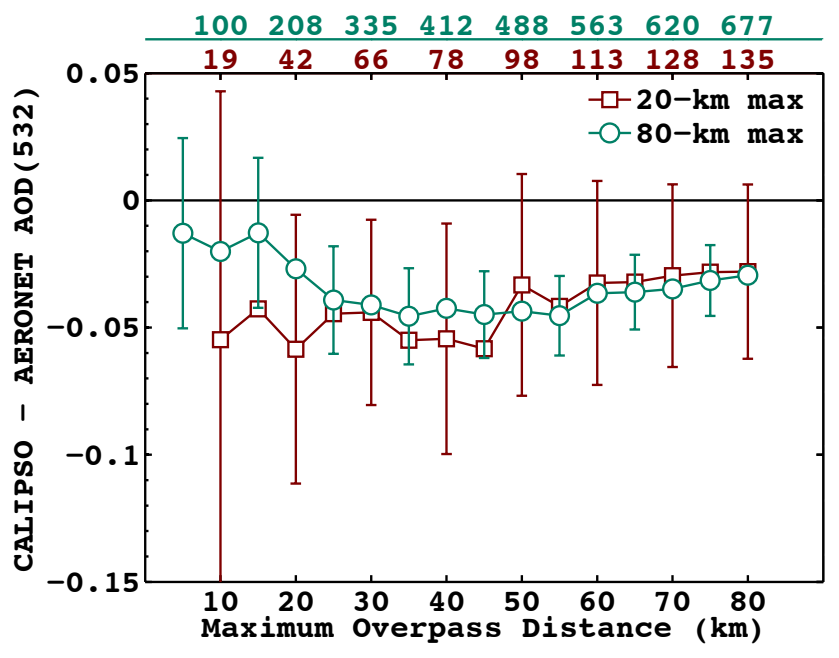

Fig. 3. Mean difference between CALIPSO and AERONET aerosol optical depths $(0.532 \mu \mathrm{m}$ wavelength) as a function of maximum satellite overpass distance for two different averaging scales in the CALIPSO product. Sampling that allows $80-\mathrm{km}$ horizontal averaging produces results similar to a subset of the data that considers only 5 or $20 \mathrm{~km}$ horizontal averages. The number of samples for each maximum distance are shown along the upper axes, and error bars indicate standard deviation of the mean.

AERONET sites produce favorable comparisons; we've done it here only to show that spatial collocation is not the main cause of aerosol optical depth discrepancy at distances up to $80 \mathrm{~km}$.

\subsection{CALIPSO horizontal averaging}

Horizontal averaging distances for aerosol properties in the CALIPSO data product are 5,20 , and $80 \mathrm{~km}$. AERONET operates only in daylight, and this is the most challenging time for CALIPSO retrievals (because of solar radiation scattering into the lidar telescope). Hence, most of the CALIPSO retrievals in our comparison require $80-\mathrm{km}$ averaging in at least one vertical layer. Of the 677 synchronized overpasses within $80 \mathrm{~km}$ of AERONET sites during our 3-yr study period, 542 of them $(80 \%)$ require $80-\mathrm{km}$ averaging in at least one aerosol layer, $93(14 \%)$ have a maximum CALIPSO averaging distance of $20 \mathrm{~km}$, and $42(6 \%)$ have a maximum CALIPSO averaging distance of $5 \mathrm{~km}$. Thus, it is desirable to use the $80-\mathrm{km}$ averages if there are no detrimental effects (which we investigate next).

The effect of the CALIPSO horizontal averaging scale on our comparison to AERONET surface data is shown in Fig. 3. Circles represent average values for all available overpasses within the maximum overpass distance. Squares represent a subset of the dataset that considers only 5 and $20 \mathrm{~km}$ horizontal averages. The upper axes indicate the sampling size for the circles (100-677) and squares (19-135). Error bars indicate one standard deviation of the mean for the corresponding averages.
The absolute differences for the two averaging schemes in Fig. 3 are very similar, and are nearly identical at distances greater than $55 \mathrm{~km}$, where both the CALIPSO and AERONET AODs converge to a nearly constant value. Note that there are far fewer overpasses for the $20-\mathrm{km}$ maximum averaging than the $80-\mathrm{km}$ maximum averaging, so the error bars are much larger for the $20-\mathrm{km}$ comparisons. The small sample size of the $20-\mathrm{km}$ comparisons also prohibits further subsampling by region, season, or aerosol subtype. Hence, the statistical similarity of the two averaging schemes at all overpass distances shown in Fig. 3 justifies the use of all horizontal averages in the CALIPSO aerosol data product (i.e., 5,20 , and $80 \mathrm{~km}$ ).

Furthermore, since $80 \%$ of the clear-sky CALIPSO retrievals in our analysis require $80-\mathrm{km}$ horizontal averaging in at least one aerosol layer, it makes little sense to require overpass distances less than $80 \mathrm{~km}$. This is because the natural autocorrelation of the aerosols within an 80-km "sheet" provided by CALIPSO limits the maximum correlation that can be expected in a comparison with another instrument, even if the satellite always passes directly overhead. Reducing the maximum overpass distance from $80 \mathrm{~km}$ to values as low as $30 \mathrm{~km}$ actually results in a slightly degraded absolute bias (as shown in Fig. 3). Hence, the use of satellite overpasses up to $80 \mathrm{~km}$ away from AERONET sites and CALIPSO horizontal averages of $80 \mathrm{~km}$ is justified for this aerosol optical depth comparison.

\subsection{Time synchronization}

AERONET obtains AOD measurements every 5-25 min, depending upon the solar zenith angle (Holben et al., 1998). Data gaps longer than 25 min can be caused by Level 2 cloud screening or instrument malfunction, but most of the data gaps within a particular day are caused by cloud screening (since field instrument malfunctions are rarely resolved within $25 \mathrm{~min}$ of their origination). Non-standard AERONET sampling intervals usually indicate broken cloud fields (Koren et al., 2007), which can indicate non-uniform aerosol fields (Loeb and Schuster, 2008; Su et al., 2008). Inhomogeneous aerosol fields add noise to our comparisons, so we choose CALIPSO closest-approaches that are within $30 \mathrm{~min}$ of an AERONET AOD measurement. Nonetheless, most of the CALIPSO overpasses for our comparisons ( $87 \%$ ) occur within 15 min of an AERONET measurement.

\section{Results}

The global results of Figs. 1-3 do not provide information about which CALIPSO aerosol subtypes are the most error prone, or where in the world the CALIPSO optical depths show the largest discrepancy with AERONET optical depth measurements. Hence, we analyze the optical depth results 


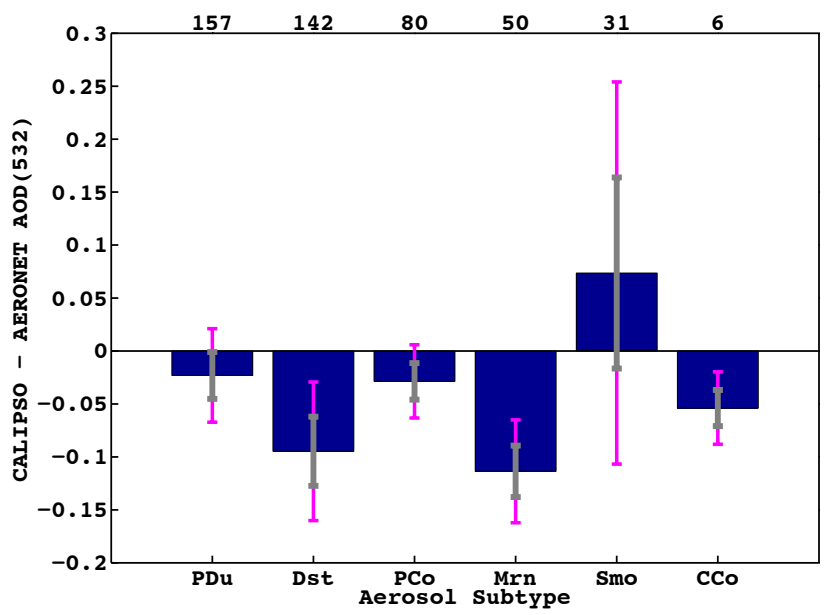

Fig. 4. Absolute bias with $67 \%$ and $95 \%$ confidence intervals for 515 overpasses with a single CALIPSO aerosol subtype throughout the column. CALIPSO aerosol subtypes include polluted dust (PDu), dust (Dst), polluted continental (PCo), marine (Mrn), smoke (Smo), and clean continental (CCo). Number of overpasses per subtype are indicated by the top row of numbers.

by aerosol subtype in Sect. 3.1 and for eight regions in Sect. 3.2.

\subsection{Aerosol subtypes analysis}

Consider atmospheres with a single CALIPSO aerosol subtype in the atmospheric column during the closest approach (i.e., disallow dust layers over marine aerosol layers, smoke over dust, etc.). There are 466 overpasses that satisfy this single-subtype requirement and the requirements of Table 1 during the 3-yr study period. We define absolute bias as the average CALIPSO optical depth $\left(\overline{\tau_{\mathrm{C}}}\right)$ minus the average AERONET optical depth $\left(\overline{\tau_{\mathrm{A}}}\right)$,

$B_{\mathrm{a}}=\overline{\tau_{\mathrm{C}}}-\overline{\tau_{\mathrm{A}}}$,

and plot it for the six CALIPSO aerosol subtypes in Fig. 4. The shortest confidence levels in Fig. 4 (gray error bars) indicate the standard error, or equivalently, the standard deviation of the mean; the largest confidence levels in Fig. 4 denote twice the standard error. Hence, the largest confidence levels correspond to Student's t-test values of $|t| \leq 2$, where $t$ is defined as (Storch and Zwiers, 1999)

$t=\frac{B_{\mathrm{a}}}{\sigma_{\mathrm{a}}}$.

Here, $\sigma_{\mathrm{a}}=\sqrt{\sigma_{\mathrm{C}}^{2}+\sigma_{\mathrm{A}}^{2}}$ is the standard error of $B_{\mathrm{a}} ; \sigma_{\mathrm{C}}$ and $\sigma_{\mathrm{A}}$ are the standard errors of the CALIPSO and AERONET data.

The $t$-score has a specific meaning when the distribution of biases is lognormally distributed (see Storch and Zwiers, 1999 , for example). In this case, the $t$-score is associated with its sister parameter, $p$-value (p), which is the probability that a given difference of means is caused exclusively by random errors. Magnitudes of $|t| \geq 2$ have $p$-values $p \leq 0.05$, and indicate a less than $5 \%$ probability that the absolute bias is caused by random errors. The null hypothesis is said to be rejected at the $95 \%$ confidence level (and the confidence bars do not touch the zero line in Fig. 4). Rejection of the null hypothesis is equivalent to stating that biases are "statistically significant."

However, the distribution of biases is not exactly lognormal in our case, so we can not interpret the $p$-values too literally. Nonetheless, we reasonably conclude that the null hypothesis can be rejected with "very high confidence" when $|t| \geq 2$ (and therefore, $p \leq 0.05$ ), rejected with "high confidence" when $1 \leq|t|<2(0.05<p \leq 0.33)$, rejected with "marginal confidence" when $0.67 \leq|t|<1 \quad(0.33<$ $p \leq 0.5)$, and cannot be rejected with any confidence at all when $|t|<0.67(p>0.5)$.

The $t$-scores and $p$-values for Fig. 4 are shown in Table 2. Other statistics shown in Table 2 are the correlation coefficient $(R)$, the number of CALIPSO overpasses $(N)$ within $80 \mathrm{~km}$ of an AERONET site, the relative bias

$B_{\mathrm{r}}=\overline{\tau_{\mathrm{C}}} / \overline{\tau_{\mathrm{A}}}-1$,

and the RMS error,

$\mathrm{RMS}=\sqrt{\frac{\sum_{i}\left(\tau_{\mathrm{C}, i}-\tau_{\mathrm{A}, i}\right)^{2}}{N}}$.

Here, $\tau_{\mathrm{C}, i}$ and $\tau_{\mathrm{A}, i}$ are the optical depths provided by the CALIPSO and AERONET data products during the CALIPSO satellite overpass.

The biases and confidence intervals in Fig. 4 and Table 2 demonstrate that the null hypothesis can be rejected with very high confidence for marine and dust aerosols, and that the bias for these subtypes is therefore statistically significant. (Note that a significant difference exists for clean continental aerosols as well, but the sample size is too small for a robust discussion.) Hence, we analyze these aerosol subtypes with greater detail in the following sections.

\subsubsection{Maritime biases}

There are 50 overpasses over 33 AERONET sites where CALIPSO indicates "marine-only" aerosols in the atmospheric column during the closest approach. The CALIPSO satellite is always over water when it finds these marine aerosol types, as this is a requirement for the CALIPSO retrieval algorithm (Omar et al., 2009). Many of the maritime overpasses occur at coastal continental AERONET sites (rather than island sites), as shown in Fig. 5. Coastal regions are aerosol transition zones, where pollution plumes fade as they are dispersed over the open water. Since the CALIOP beam can be up to $80 \mathrm{~km}$ from the coast in our analysis, it is quite possible that the CALIOP instrument is 


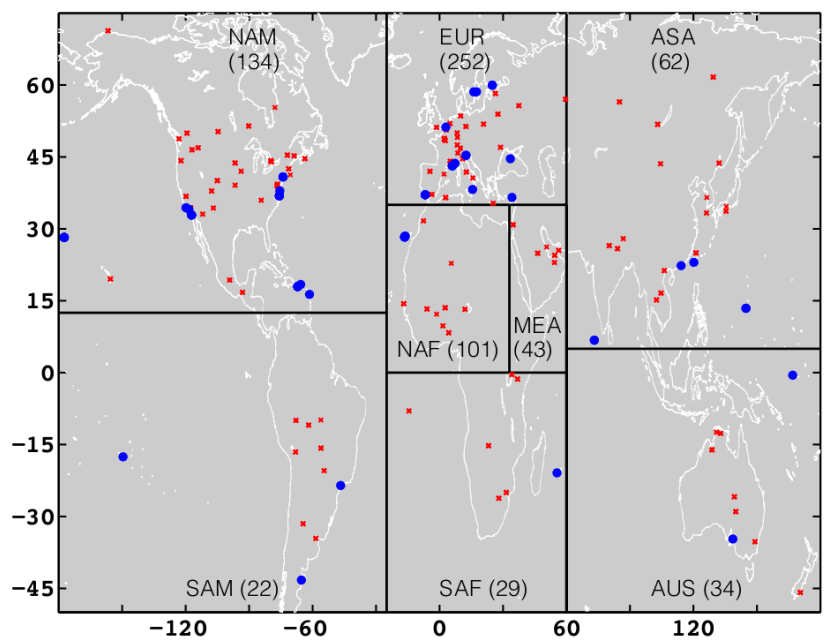

Fig. 5. Regional boundaries and locations of the 147 AERONET sites used in this study. The blue dots indicate AERONET sites where CALIPSO retrieves the marine aerosol subtype for all detected aerosol layers in the column during at least one closest approach. Number of closest approaches in North America (nam), Europe (eur), Asia (asa), South America (sam), Northern Africa (naf), Middle East (mea), Southern Africa (saf), and Australia (aus) are shown in parentheses.

observing an atmospheric column outside of the continental aerosol plume (and a significantly lower aerosol optical depth) while the corresponding AERONET instrument is observing a pollution plume over land. The AERONET sites are always closer to aerosol sources than the CALIOP beam in these cases, which produces a negative bias.

Another possible reason for the marine aerosol discrepancy is "mistyping" by the CALIPSO algorithm. CALIPSO labels non-elevated aerosol layers over ocean as "marine" if the integrated attenuated backscatter at $0.532 \mu \mathrm{m}$ is greater than 0.01 or the volume depolarization ratio is less than 0.05 , and as polluted continental otherwise. Pollution aerosols can be highly hygroscopic (and therefore, spherical), and may have depolarizations below the 0.05 threshold. CALIPSO uses a lidar ratio of 70 for polluted continental aerosols, and a value of 20 for marine aerosols, so mistyping (or a sampling mismatch) has a dramatic effect on the comparisons.

We emphasize that discrepancies associated with land/water sampling differences and errors associated with mistyping pollution aerosols as marine aerosols are much more likely in coastal areas than over the open ocean. This is corroborated with data from NASA's high spectral resolution lidar, which has measured marine aerosol lidar ratios that are consistent with the CALIPSO model in open oceans $(15-25 \mathrm{sr})$, and much higher values $(35-45 \mathrm{sr})$ in mixtures of marine aerosol and continental pollution found in coastal regions (Burton et al., 2012). Hence, the statistics in Fig. 4 and Table 2 are not representative CALIPSO aerosol optical depth errors over the open ocean.

\subsubsection{Dust biases}

The dust aerosol statistics shown in Fig. 4 and Table 2 indicate a significant bias $\left(B_{\mathrm{a}}=-0.1\right)$. In addition to the large absolute bias, dust has a large relative bias $\left(B_{\mathrm{r}}=-0.29\right)$ and a large RMS bias (RMS $=0.27$ ). Conversely, it also has one of the highest correlation coefficients of all of the aerosol subtypes $(R=0.575)$. The high correlation and low relative bias indicates that the dust aerosols are generally being "typed" correctly over the AERONET sites, but that perhaps the assigned lidar ratio for dust is too low.

CALIPSO uses a lidar ratio $\left(S_{532}\right)$ of $40 \mathrm{sr}$ for dust $(532 \mathrm{~nm}$ wavelength), which is based upon discrete dipole approximation calculations (Omar et al., 2009; Kalashnikova and Sokolik, 2002). This value is consistent with high spectral resolution lidar (HSRL) measurements of $S_{532}=46 \mathrm{sr}$ for dust over the Gulf of Mexico (Liu et al., 2008), computations of $S_{532}=39$ sr using T-matrix theory with in situ measurements near the Cape Verde Islands (Omar et al., 2010), and with $S_{\mathrm{a}}=42 \pm 4 \mathrm{sr}$ derived from previous studies using AERONET data (Cattrall et al., 2005).

Nonetheless, the variability of lidar ratios reported for long-range dust transport towards Europe and North America is large, and ranges from 30 to $80 \mathrm{sr}$ (Mattis et al., 2002; Mona et al., 2006; Papayannis et al., 2008; Liu et al., 2008; Tesche et al., 2009). Causes for this range of values include variations in dust particle sizes, shapes, and refractive indices, mixing with marine or pollution aerosols, and uncertainty in some lidar ratio retrieval techniques (Tesche et al., 2009; Wiegner et al., 2009). Refractive index variability is the dominant cause of $S_{532}$ variability over the AERONET sites in the dust belt, which we discuss in Sect. 4.

Non-dust aerosols can also be "mistyped" as dust by the CALIOP algorithm; this mistyping of aerosols can lead the CALIOP algorithm to choose an incorrect lidar ratio, which would contribute to the aerosol optical depth bias. Since the dust comparisons of this section requires CALIPSO to classify all aerosol layers as dust, most of the comparisons should occur in the dust belt. Indeed, this is the case, as 60 of the 142 comparisons occur over Northern Africa, 25 occur in the Middle East, 25 over Europe, 14 over North America, 9 over Australia, 5 over Asia, 2 over Southern Africa, and 2 over South America.

\subsection{Regional analysis}

We divide the world into eight regions, as first suggested by Chin et al. (2009) and shown in Fig. 5. (The large geographical extent of the regions is required to maintain reasonable sample sizes.) The absolute bias, relative bias, and correlation coefficients for the five regions with the most overpasses are shown in Fig. 6. The range of single-instrument autocorrelations measured at a distance of $80 \mathrm{~km}$ by Anderson et al. (2003) is shown as the grey shaded area in Fig. 6 $(R=0.62-0.88)$, and represents a reasonable upper limit for 
Table 3. Regional statistics for CALIPSO and AERONET comparisons with a maximum closest approach of $80 \mathrm{~km}$, including cases without marine or dust aerosols. Average AERONET aerosol optical depth at $0.532 \mu \mathrm{m}\left(\overline{\tau_{\mathrm{A}}}\right)$, absolute bias and absolute standard error $\left(B_{\mathrm{a}}, \sigma_{\mathrm{a}}\right)$, student's t-test score and $p$-value $(t, p)$, relative bias, $\left(B_{\mathrm{r}}\right)$, root-mean-square error (RMS), correlation coefficient $(R)$, and number of comparisons $(N)$ are shown. Regions denoted with $(* *)$ indicate absolute biases that exceed the $95 \%$ confidence interval of the means (i.e., $t$-score magnitudes greater than 2 and $p$-values less than 0.05 ). Regions denoted with $\left(^{*}\right)$ indicate absolute biases that exceed the $67 \%$ confidence interval of the means. Regions with less than 43 overpasses are shown in bold.

\begin{tabular}{|c|c|c|c|c|c|c|c|c|c|}
\hline Region & $\overline{\tau_{A}}$ & $B_{\mathrm{a}}$ & $\sigma_{\mathrm{a}}$ & $t$ & $p$ & $B_{\mathrm{r}}$ & RMS & $R$ & $N$ \\
\hline & \multicolumn{9}{|c|}{ All Aerosol Subtypes } \\
\hline World ${ }^{* *}$ & 0.231 & -0.029 & 0.014 & -2.164 & 0.031 & -0.127 & 0.270 & 0.429 & 677 \\
\hline Europe* & 0.181 & -0.022 & 0.015 & -1.430 & 0.154 & -0.119 & 0.205 & 0.320 & 252 \\
\hline North America** & 0.165 & -0.049 & 0.020 & -2.419 & 0.016 & -0.298 & 0.214 & 0.219 & 134 \\
\hline North Africa* & 0.395 & -0.080 & 0.047 & -1.694 & 0.092 & -0.202 & 0.373 & 0.405 & 101 \\
\hline Asia & 0.319 & -0.023 & 0.048 & -0.476 & 0.635 & -0.072 & 0.194 & 0.775 & 62 \\
\hline Middle East & 0.290 & -0.034 & 0.048 & -0.723 & 0.472 & -0.119 & 0.239 & 0.442 & 43 \\
\hline Australia* & 0.071 & 0.079 & 0.061 & 1.308 & 0.199 & 1.118 & 0.355 & 0.029 & 34 \\
\hline South Africa* & 0.247 & 0.104 & 0.091 & 1.153 & 0.257 & 0.422 & 0.426 & 0.509 & 29 \\
\hline \multirow[t]{2}{*}{ South America } & 0.314 & -0.120 & 0.124 & -0.967 & 0.341 & -0.381 & 0.447 & 0.540 & 22 \\
\hline & \multicolumn{9}{|c|}{ All Subtypes Except Marine } \\
\hline World* & 0.241 & -0.023 & 0.015 & -1.491 & 0.136 & -0.093 & 0.273 & 0.447 & 581 \\
\hline Europe & 0.179 & -0.008 & 0.017 & -0.458 & 0.647 & -0.043 & 0.210 & 0.338 & 222 \\
\hline North America* & 0.168 & -0.033 & 0.025 & -1.307 & 0.193 & -0.197 & 0.220 & 0.265 & 98 \\
\hline North Africa** & 0.442 & -0.113 & 0.049 & -2.314 & 0.022 & -0.256 & 0.346 & 0.473 & 86 \\
\hline Asia & 0.327 & -0.001 & 0.053 & -0.019 & 0.985 & -0.003 & 0.191 & 0.803 & 53 \\
\hline Middle East & 0.290 & -0.034 & 0.048 & -0.723 & 0.472 & -0.119 & 0.239 & 0.442 & 43 \\
\hline Australia* & 0.072 & 0.088 & 0.066 & 1.331 & 0.192 & 1.218 & 0.372 & 0.022 & 31 \\
\hline South Africa* & 0.252 & 0.108 & 0.093 & 1.162 & 0.254 & 0.430 & 0.433 & 0.502 & 28 \\
\hline \multirow[t]{2}{*}{ South America } & 0.338 & -0.132 & 0.135 & -0.982 & 0.335 & -0.391 & 0.469 & 0.529 & 20 \\
\hline & \multicolumn{9}{|c|}{ All Subtypes Except Dust } \\
\hline World & 0.189 & -0.005 & 0.016 & -0.346 & 0.730 & -0.028 & 0.261 & 0.397 & 449 \\
\hline Europe & 0.170 & -0.001 & 0.018 & -0.074 & 0.941 & -0.008 & 0.216 & 0.326 & 203 \\
\hline North America* & 0.172 & -0.047 & 0.024 & -1.961 & 0.051 & -0.273 & 0.230 & 0.212 & 112 \\
\hline North Africa & 0.138 & 0.001 & 0.045 & 0.026 & 0.979 & 0.008 & 0.109 & 0.636 & 17 \\
\hline Asia & 0.312 & -0.020 & 0.059 & -0.341 & 0.734 & -0.065 & 0.186 & 0.842 & 46 \\
\hline Middle East & 0.153 & 0.010 & 0.048 & 0.215 & 0.833 & 0.068 & 0.063 & 0.907 & 9 \\
\hline Australia* & 0.061 & 0.130 & 0.083 & 1.571 & 0.130 & 2.147 & 0.412 & 0.218 & 24 \\
\hline South Africa* & 0.256 & 0.156 & 0.110 & 1.414 & 0.170 & 0.611 & 0.472 & 0.507 & 23 \\
\hline \multirow[t]{2}{*}{ South America* } & 0.377 & -0.185 & 0.177 & -1.043 & 0.310 & -0.490 & 0.524 & 0.606 & 15 \\
\hline & \multicolumn{9}{|c|}{ All Subtypes Except Marine and Dust } \\
\hline World & 0.193 & 0.015 & 0.018 & 0.828 & 0.408 & 0.079 & 0.278 & 0.412 & 364 \\
\hline Europe & 0.166 & 0.017 & 0.020 & 0.854 & 0.394 & 0.101 & 0.222 & 0.365 & 178 \\
\hline North America & 0.179 & -0.025 & 0.032 & -0.791 & 0.430 & -0.141 & 0.244 & 0.251 & 76 \\
\hline North Africa & 0.207 & 0.056 & 0.133 & 0.423 & 0.683 & 0.272 & 0.176 & 0.610 & 5 \\
\hline Asia & 0.314 & 0.005 & 0.067 & 0.070 & 0.944 & 0.015 & 0.178 & 0.885 & 39 \\
\hline Middle East & 0.153 & 0.010 & 0.048 & 0.215 & 0.833 & 0.068 & 0.063 & 0.907 & 9 \\
\hline Australia* & 0.061 & 0.150 & 0.094 & 1.601 & 0.125 & 2.456 & 0.441 & 0.214 & 21 \\
\hline South Africa* & 0.262 & 0.164 & 0.114 & 1.428 & 0.166 & 0.624 & 0.483 & 0.495 & 22 \\
\hline South America* & 0.398 & -0.200 & 0.189 & -1.063 & 0.302 & -0.503 & 0.543 & 0.603 & 14 \\
\hline
\end{tabular}


All CALIPSO Subtypes

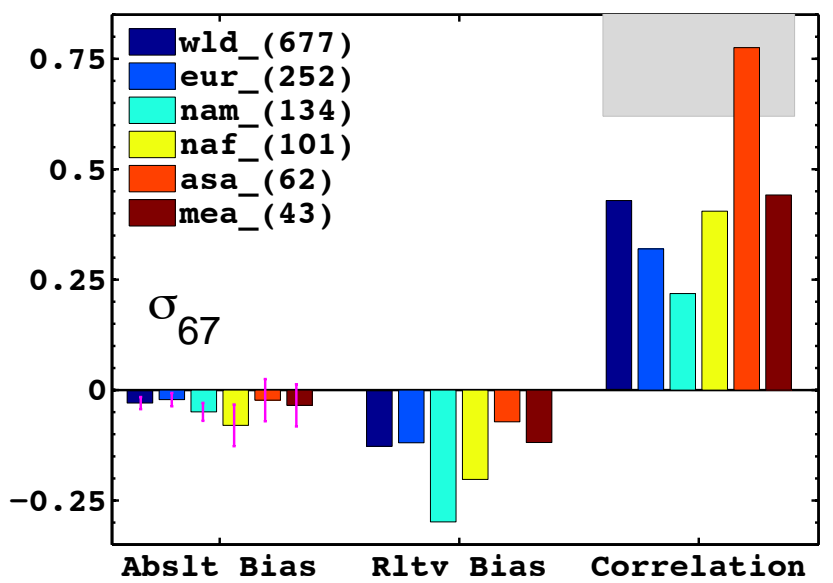

Fig. 6. Absolute bias $\left(B_{\mathrm{a}}\right)$, relative bias $\left(B_{\mathrm{r}}\right)$, and correlation coefficient $(R)$ for the four regions shown in Fig. 5 with the largest sample sizes (i.e., Europe, North Africa, North America, Asia, and the Middle East) and all seven regions (wld). Gray shaded area represents range of $80-\mathrm{km}$ aerosol autocorrelations measured by Anderson et al. (2003).

our two-instrument comparison. The remaining regions not shown in Fig. 6 have less than 43 overpasses, and are indicated by bold in Table 3 . In addition to the statistics shown for the five regions in Fig. 6, Table 3 also provides the average $\tau_{\mathrm{A}}(532), t$-scores, $p$-values, absolute standard error, RMS error, and the number of synchronized overpasses for all of the regions in Fig. 5.

Figure 6 and Table 3 indicate that the null hypothesis is rejected with high confidence or very high confidence for $\mathrm{Eu}-$ rope, North America, and North Africa; thus, the absolute biases of $-0.02,-0.05$ and -0.08 for those three regions are likely to represent real differences in the datasets that are not associated with random errors. The corresponding relative biases are $-12,-30$ and $-20 \%$. These three regions contain a large fraction of the overpasses (72\%), so the null hypothesis does not hold for the entire dataset (i.e., $|t|>2$ for "World"), and the relative bias for the dataset as a whole is $-13 \%$.

Interestingly, the $p$-value for the Middle East region is 0.47 (per Table 3), indicating marginal confidence for rejection of the null hypothesis. This is somewhat surprising, since the nearby North Africa region has such a significant bias (i.e., $p=0.09$ ) and both regions are dominated by dust aerosols. However, the mineralogical composition of dust aerosols in the Middle East are much different than African dust, so the lidar ratio is different as well. This is discussed further in Sect. 4.

\subsubsection{Omission of dust and marine aerosol subtypes}

We found that the dust and marine CALIPSO subtypes have the most significant biases (see Sect. 3.1), so we investigate

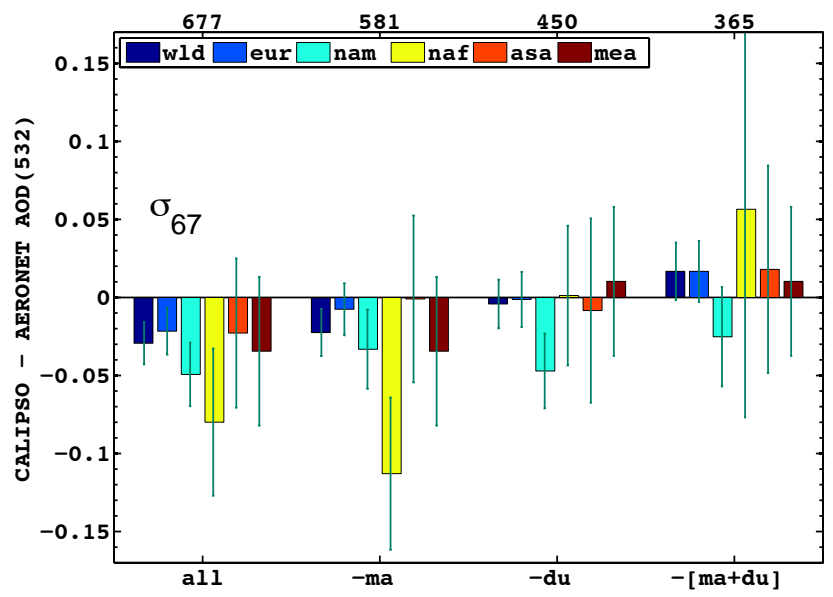

Fig. 7. Absolute bias for all CALIPSO aerosol subtypes (all), all subtypes except marine (-ma), all subtypes except dust (-du), and all subtypes except marine and dust $(-[\mathrm{ma}+\mathrm{du}])$. The color of the bars correspond to the five regions in Fig. 5 with the largest sample sizes and all eight regions (wld). Numbers along the top axis indicate the total number of synchronized overpasses for all eight regions (wld).

the impact of omitting these aerosol subtypes from our analysis (clean continental also indicates a significant bias, but there are only nine cases). The results of this test are shown in Fig. 7 and Table 3. Omitting overpasses that include marine aerosols from the analysis significantly reduces the absolute and relative biases and absolute $t$-values for Europe, North America, and Asia. Omitting overpasses with marine aerosols has a detrimental effect on biases and $t$-values North Africa though, and the null hypothesis is rejected with high confidence for the world dataset.

Next, we test to see if the regional results can be improved by omitting dust. Omitting dust significantly improves the biases and $t$-scores in Europe and North Africa. Although the improvements for North Africa shown in Fig. 7 and Table 3 are substantial, the sampling is reduced dramatically (from 101 overpasses to 17 overpasses, per Table 3). Global results also indicate strong $t$-scores and $p$-values when dust is omitted from the analysis (note that the null hypothesis can no longer be rejected with any confidence, since $|t| \ll 0.67$ ); the magnitude of the absolute bias is less than 0.01 and the magnitude of the relative bias is less than $3 \%$.

Finally, we omit both marine and dust aerosols from the analysis for completeness. Only two regions have more than 43 points with this scenario - Europe and North America. Results degrade in Europe with respect to the "except dust" case, but the null hypothesis can not be rejected with high confidence in either of these regions (since $|t|<1$ ). Similarly, the null hypothesis for the world dataset can not be rejected with high confidence, so the global bias is not statistically significant when both marine and dust aerosols are not present. 
The world results are summarized as follows. The null hypothesis is rejected with very high confidence when all CALIPSO subtypes are included in the analysis, indicating a significant difference between the CALIPSO and AERONET datasets; the absolute bias is -0.029 , and the relative bias is $-12.7 \%$ for 677 overpasses. Although results are improved in some regions when overpasses with marine aerosols are not included in the analysis, the bias is still statistically significant at the high confidence level. The magnitude of the absolute bias is reduced by 0.006 to -0.023 , and the magnitude of the relative bias is reduced by $3.4 \%$ to $-9.3 \%$ for 581 overpasses. Results improve dramatically if dust is not included in the analysis, resulting in a global absolute bias of -0.005 and a relative bias of $-2.8 \%$ for 449 overpasses. Note that our world statistics (wld) are not representative of a global result, though, as the locations of the AERONET sites produce sampling that is heavily weighted toward Europe, North Africa, and North America (see last column of Table 3).

\section{A closer look at dust}

Since dust aerosols have the one of the smallest $p$-values of the CALIPSO subtypes (see Table 2) and its omission results in a dramatic improvement to the global results (Table 3 and Fig. 7), we explore this subtype further in this section. Recall that omitting aerosol columns with CALIPSO dust types reduces the global relative bias from -0.13 to -0.03 and the global absolute bias from -0.03 to -0.005 . The $p$-value also increases dramatically with the omission of dust (from 0.031 to 0.73 ), indicating that the bias between the CALIPSO and AERONET optical depths are not statistically significant when dust is not present. The correlation of AERONET and CALIPSO AOD is very good for dust, though (Table 2), indicating a systematic bias for this CALIPSO subtype. This raises the possibility that using a different lidar ratio for the CALIPSO dust subtype would produce better AOD comparisons with the AERONET sites. Hence, we explore this possibility by using the AERONET almucantar retrievals to compute lidar ratios at the AERONET sites in North Africa and the Middle East (where the dust subtype dominates other aerosol types). We can then compare these retrieved lidar ratios to the value of $40 \mathrm{sr}$ used for dust in the CALIPSO AOD retrievals.

AERONET provides several aerosol products, and in Sects. 2 and 3 we utilized only the AERONET AOD product. However, the advanced products in the AERONET Level 2.0 database also provide column retrievals of aerosol size distributions at 22 radii between 0.05 and $15 \mu \mathrm{m}$, complex refractive indices at approximately $0.440,0.675,0.870$, and $1.020 \mu \mathrm{m}$, and the fraction of the aerosols that can be approximated as spheres (Dubovik and King, 2000; Dubovik et al., 2002, 2006). Pertinent assumptions of the retrievals are that the aerosols are distributed throughout a single atmospheric layer, particles of all sizes have the same refractive index, and that nonspherical aerosols may be represented by oblate and prolate spheroids with a single axis ratio distribution.

The original AERONET algorithm by Dubovik and King (2000) assumed aerosols as a mixture of polydisperse spheres with size independent refractive index, and Dubovik et al. (2000) presents an error analysis of the retrieval products for this version of the algorithm. This study identified the presence of significant bias in the retrievals for desert dust aerosols caused by particle non-sphericity. In order to address this issue, Dubovik et al. (2002) suggested an alternative retrieval that assumes aerosols as an ensemble of randomly oriented polydisperse spheroids with a fixed aspect ratio distribution. As a result, the AERONET data base was providing two retrieval products at that time; one product using the spherical aerosol assumption, and another product using the non-sphercial aerosol model. In the latest version of AERONET retrieval algorithm (i.e., Level 2, Version 2 products), aerosols are now considered to be a mixture of spherical and non-spherical aerosols with the same complex refractive index and size distribution. The number fraction of spheres is also retrieved, although this parameter is assumed to be constant with respect to particle size. The non-spherical particles are modeled as an ensemble of randomly oriented spheroids with a fixed aspect ratio distribution; the chosen aspect ratio distribution provides the best fit of the spheroid model (Dubovik et al., 2006) to the scattering matrices of feldspar samples that were measured by Volten et al. (2001). Additional details are available in Dubovik et al. (2011).

There is enough information in the AERONET retrievals to compute the lidar and depolarization ratios at 0.532 and $1.064 \mu \mathrm{m}$ with the Dubovik et al. (2006) code, which we utilize in this section McPherson et al. (2010); Repasky et al. (2011). We obtain complex refractive indices at $0.532 \mu \mathrm{m}$ from the AERONET database by linearly interpolating between the 0.440 and $0.670 \mu \mathrm{m}$ wavelengths, and we use the complex refractive indices at $1.02 \mu \mathrm{m}$ for computations $1.064 \mu \mathrm{m}$. These refractive indices can then be used with the size distributions and the fraction of spheres found in the AERONET database (and the aspect ratio distributions of Dubovik et al., 2006) to compute the phase matrix at 180 degrees and the single scatter albedo. Once the phase matrix and single scatter albedo are known, the lidar and depolarization ratios are easily computed by insertion into Eqs. (34)(35) of Dubovik et al. (2006).

We note that it is important to retrieve the correct backscattering phase function for these lidar ratio computations, and this is possible for size distributions with irregularly-shaped particles using the spheroid approximation (at least in some cases; see Nousiainen, 2009). Also, although it is not possible to directly measure the aerosol backscatter phase function with the AERONET instrument, the Level 2.0 AERONET products are constrained to measured radiances at scattering angles of 3 to $100-154$ degrees (depending upon the solar zenith angle). Single-scatter albedo is the other important 

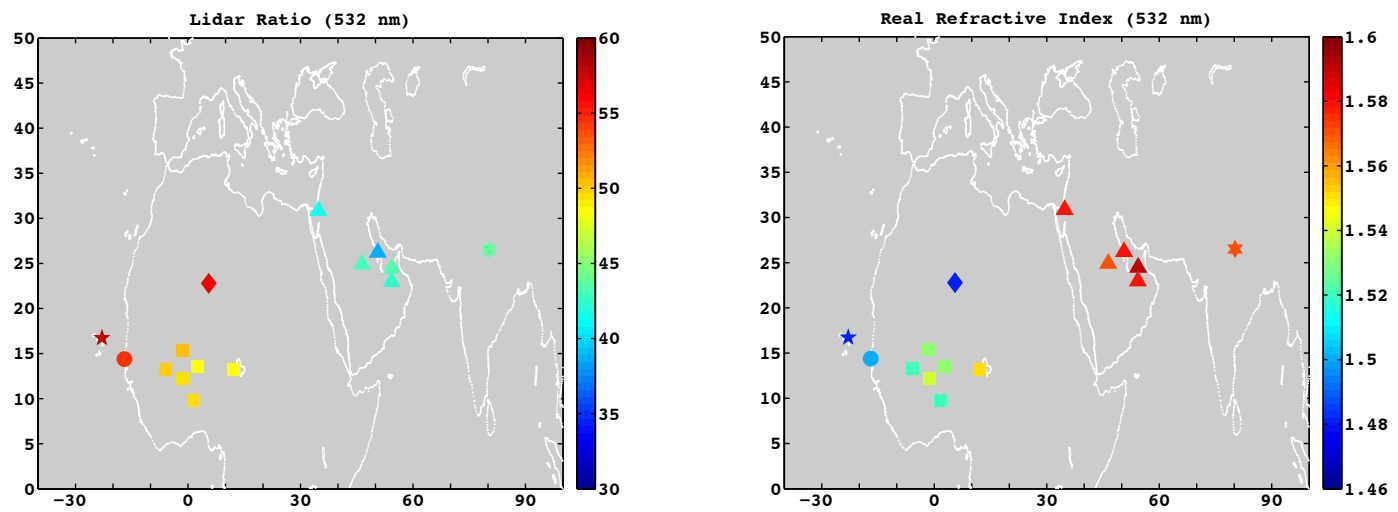

Fig. 8. Left panel: Median lidar ratios computed for Level 2.0 AERONET retrievals approximating "pure" dust (i.e., depolarizations greater than 0.2 and fine volume fractions less than 0.05). Right panel: same retrievals as left panel, except the median real refractive index at $0.532 \mu \mathrm{m}$ is shown. Both lidar ratio and refractive index indicate regional consistency and large scale variability (i.e, non-Sahel Africa is different than the African Sahel and the Middle East).

parameter for determining the lidar ratio, and the accuracy of the single-scatter albedo for dust in the Level 2.0 AERONET database is estimated to be 0.03 (Dubovik et al., 2000).

Unfortunately, the advanced AERONET products are not available as frequently as the AERONET AOD product, so a statistically significant computation of lidar ratios during CALIPSO overpasses is not possible with the advanced products. Thus, we present climatological values using all available AERONET retrievals in this section.

\subsection{AERONET lidar ratios for "pure" dust}

In an effort to focus on dust, we limit our analysis to retrievals over Africa and parts of Asia during the summer months (May through September). This covers the peak dust seasons in Northern Africa, the Middle East, and India (Prospero et al., 2002) and avoids the biomass burning season of Northern Africa. The CALIPSO product defines dust as aerosol layers with depolarization ratios greater than 0.2 at $0.532 \mu \mathrm{m}$ for aerosols that are not located over snow, ice, or tundra, so we use this constraint as well. We consider this to be a relatively conservative constraint for the AERONET lidar ratios, since Merikallio et al. (2011) found the depolarization ratio of spheroids to be biased low of measured values for several dust samples. Additionally, we require the aerosol fine mode volume fraction (fvf) to be less than 0.05 for the "pure" dust of this section. We computed lidar ratios for 7745 AERONET retrievals within these limitations, and $97 \%$ of those retrievals had $\tau_{\mathrm{A}}(440) \leq 1.5$.

Median lidar ratios and refractive indices for 15 AERONET sites with more than 10 Level 2.0 retrievals are shown in Fig. 8 and tabulated in Table 4. These results clearly indicate significant variability between regions, with sites in the Middle East and India (triangles and hexagram) having much lower lidar ratios and higher refractive indices than sites in the Sahel (squares), which in turn have lower lidar

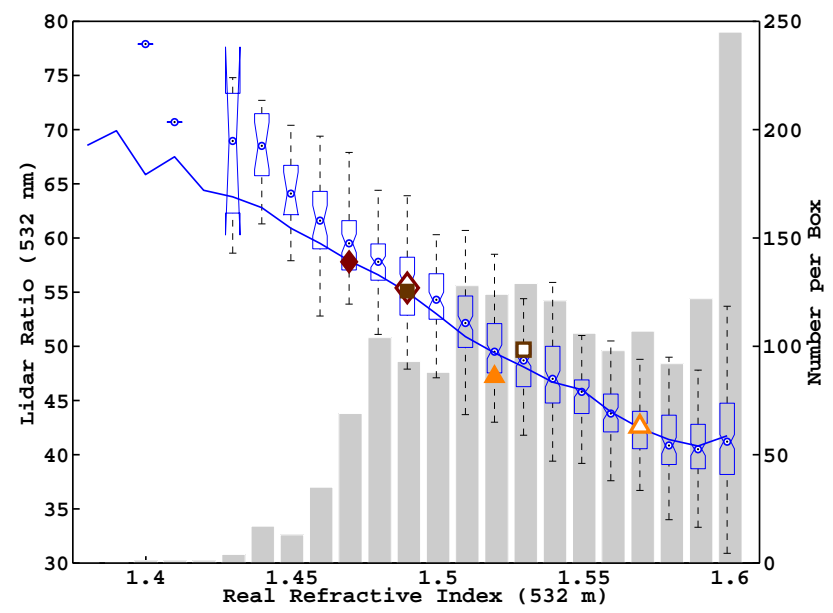

Fig. 9. Lidar ratio is highly anti-correlated with the real refractive index of dust, as shown here for all the AERONET sites of Table 4. Boxplots represent all data with depolarizations greater than 0.2 and fine volume fractions less than 0.05 . Median lidar ratios are the targets at the center of the boxes, and the borders of the whiskers and boxes represent the 1, 25, 75, and 99 percentiles; gray bars indicate the number of data points for each box. The solid line is the median for all data with depolarizations greater than 0.2 and all fine volume fractions. Symbols represent regional medians for non-Sahel Africa (diamonds), African Sahel (squares), and the Middle East (triangles). Open symbols are restricted to fine volume fractions less than 0.05 .

ratios and higher refractive indices than the sole site in the Sahara desert (diamond). The Capo Verde site (pentagram) on the Cape Verde islands has the most extreme values of all the sites within this set of constraints.

We investigate the relationship between lidar ratio and the real refractive index in Fig. 9. The circles at the center of the boxplots represent median lidar ratios for the corresponding refractive index; the upper and lower bounds 
Table 4. Several parameters for "pure" dust and "all" dust at 22 AERONET sites for all data available in the months May-September with depolarization ratios greater than 0.2 . $n_{532}$ denotes the median real refractive index, fvf is median fine volume fraction, $S_{532}$ and $S_{1064}$ indicate median lidar ratios (in steradians) at 0.532 and $1.064 \mu \mathrm{m}, R_{532}$ is the correlation between lidar ratio and real refractive index at $0.532 \mu \mathrm{m}, r_{\mathrm{crs}}$ is the coarse mode effective radius, and $N$ is the number of samples.

\begin{tabular}{|c|c|c|c|c|c|c|c|c|c|c|c|c|c|c|c|}
\hline \multirow[b]{2}{*}{ Location } & & \multicolumn{7}{|c|}{ Pure Dust $(\mathrm{fvf}<0.05$, depolarization $\geq 0.2$ ) } & \multicolumn{7}{|c|}{ All Dust (depolarization $\geq 0.2$ ) } \\
\hline & & $n_{532}$ & fvf & $S_{532}$ & $S_{1064}$ & $R_{532}$ & $r_{\mathrm{crs}}$ & $N$ & $n_{532}$ & fvf & $S_{532}$ & $S_{1064}$ & $R_{532}$ & $r_{\mathrm{crs}}$ & $N$ \\
\hline \multicolumn{16}{|l|}{ Non-Sahel Africa } \\
\hline Blida & $\mathrm{B} 1$ & - & - & - & - & - & - & 3 & 1.49 & 0.09 & 54.5 & 46.4 & -0.892 & 1.68 & 105 \\
\hline Saada & $\mathrm{Sa}$ & - & - & - & - & - & - & 3 & 1.48 & 0.10 & 57.5 & 48.3 & -0.669 & 1.67 & 470 \\
\hline Santa Cruz Tenerife & $\mathrm{Te}$ & - & - & - & - & - & - & 0 & 1.47 & 0.10 & 55.7 & 53.6 & -0.788 & 1.60 & 188 \\
\hline Dahkla & $\mathrm{Da}$ & - & - & - & - & - & - & 3 & 1.49 & 0.08 & 57.3 & 52.7 & -0.484 & 1.59 & 109 \\
\hline Tamanrasset INM & $\mathrm{Ta}$ & 1.48 & 0.04 & 56.5 & 52.0 & -0.879 & 1.77 & 22 & 1.46 & 0.07 & 59.5 & 57.0 & -0.836 & 1.70 & 133 \\
\hline Tamanrasset TMP & $\mathrm{Ta}$ & - & - & - & - & - & - & 0 & 1.47 & 0.08 & 60.8 & 56.5 & -0.930 & 1.67 & 73 \\
\hline Capo Verde & $\mathrm{CV}$ & 1.48 & 0.04 & 57.8 & 53.5 & -0.806 & 1.78 & 82 & 1.46 & 0.07 & 59.8 & 56.5 & -0.566 & 1.66 & 681 \\
\hline Dakar & Dr & 1.50 & 0.04 & 54.4 & 47.4 & -0.799 & 1.77 & 116 & 1.48 & 0.07 & 56.5 & 49.2 & -0.765 & 1.67 & 714 \\
\hline \multicolumn{16}{|l|}{ African Sahel } \\
\hline Agoufou & $\mathrm{Ag}$ & 1.53 & 0.04 & 50.5 & 48.7 & -0.834 & 1.81 & 374 & 1.50 & 0.05 & 54.6 & 51.8 & -0.834 & 1.75 & 837 \\
\hline Banizoumbou & $\mathrm{Bz}$ & 1.53 & 0.04 & 48.7 & 45.9 & -0.881 & 1.83 & 257 & 1.49 & 0.07 & 55.3 & 52.3 & -0.880 & 1.73 & 918 \\
\hline IER Cinzana & IE & 1.52 & 0.04 & 49.9 & 47.3 & -0.858 & 1.80 & 138 & 1.49 & 0.07 & 55.9 & 51.0 & -0.764 & 1.71 & 689 \\
\hline DMN Maine Soroa & $\mathrm{DM}$ & 1.55 & 0.04 & 48.5 & 48.2 & -0.774 & 1.93 & 107 & 1.51 & 0.06 & 52.7 & 50.8 & -0.796 & 1.87 & 302 \\
\hline Ouagadougou & $\mathrm{Og}$ & 1.54 & 0.04 & 49.6 & 47.6 & -0.930 & 1.89 & 33 & 1.49 & 0.07 & 55.3 & 49.3 & -0.832 & 1.76 & 249 \\
\hline Djougou & $\mathrm{Dj}$ & 1.52 & 0.04 & 49.4 & 43.6 & -0.852 & 1.92 & 12 & 1.50 & 0.07 & 56.2 & 47.4 & -0.619 & 1.75 & 61 \\
\hline Ilorin & Il & - & - & - & - & - & - & 8 & 1.49 & 0.09 & 56.4 & 46.4 & -0.880 & 1.75 & 107 \\
\hline \multicolumn{16}{|l|}{ Middle East } \\
\hline Nes Ziona & NZ & - & - & - & - & - & - & 2 & 1.52 & 0.08 & 49.7 & 41.8 & -0.876 & 1.66 & 68 \\
\hline Sede Boker & SB & 1.58 & 0.04 & 41.4 & 37.2 & -0.850 & 1.85 & 12 & 1.52 & 0.07 & 50.2 & 45.7 & -0.862 & 1.76 & 101 \\
\hline Bahrain & $\mathrm{Ba}$ & 1.58 & 0.05 & 38.7 & 32.1 & -0.442 & 1.83 & 17 & 1.58 & 0.05 & 39.5 & 32.2 & -0.855 & 1.79 & 44 \\
\hline Solar Village & SV & 1.57 & 0.04 & 42.9 & 38.6 & -0.664 & 1.94 & 419 & 1.53 & 0.06 & 46.9 & 41.3 & -0.826 & 1.88 & 1273 \\
\hline Dhabi & $\mathrm{Dh}$ & 1.59 & 0.04 & 43.2 & 37.1 & -0.722 & 1.84 & 21 & 1.51 & 0.08 & 47.9 & 41.2 & -0.741 & 1.77 & 192 \\
\hline Hamim & $\mathrm{Ha}$ & 1.58 & 0.05 & 42.3 & 38.7 & -0.808 & 1.95 & 18 & 1.51 & 0.08 & 47.3 & 41.8 & -0.804 & 1.81 & 288 \\
\hline \multicolumn{16}{|l|}{ India } \\
\hline Kanpur & $\mathrm{Ka}$ & 1.57 & 0.04 & 43.8 & 33.6 & -0.511 & 2.02 & 67 & 1.55 & 0.05 & 46.2 & 36.4 & -0.701 & 1.98 & 143 \\
\hline \multicolumn{16}{|l|}{ Summaries } \\
\hline North Africa & & 1.52 & 0.04 & 50.6 & 48.0 & -0.845 & 1.82 & 1158 & 1.48 & 0.07 & 56.4 & 51.7 & -0.788 & 1.70 & 5636 \\
\hline Non-Sahel Africa & & 1.49 & 0.04 & 55.4 & 50.4 & -0.812 & 1.77 & 229 & 1.47 & 0.08 & 57.8 & 52.3 & -0.683 & 1.66 & 2473 \\
\hline African Sahel & & 1.53 & 0.04 & 49.7 & 47.4 & -0.837 & 1.84 & 929 & 1.49 & 0.06 & 55.1 & 51.2 & -0.823 & 1.75 & 3163 \\
\hline Middle East & & 1.57 & 0.04 & 42.6 & 38.3 & -0.679 & 1.93 & 489 & 1.52 & 0.07 & 47.2 & 41.4 & -0.808 & 1.85 & 1966 \\
\hline
\end{tabular}

of the whiskers and boxes represent the 1, 25, 75, and 99 percentiles. The open symbols represent regional medians for non-Sahel Africa (diamonds), African Sahel (squares), and the Middle East (triangles). The closed symbols and solid line represent medians for "all" dust (i.e., depolarization ratio is required to be greater than 0.2 , but all fine volume fractions are included in the medians). Note that there are a range of possible lidar ratios at any given real refractive index (caused by variability in the size distributions and imaginary refractive indices), but that the non-Sahel African sites have a lower median refractive index than the Sahel or Middle East sites. Consequently, the lidar ratio in the non-Sahel region is higher than the other two regions. There is a strong anti-correlation between lidar ratio and the refractive index at all of the sites, as shown in Table 4 .
Lidar ratio is also sensitive to aerosol absorption, of course, but we do not observe high correlations of lidar ratios with imaginary refractive indices for AERONET retrievals in the dust belt. Indeed, the correlation coefficient of the imaginary refractive index with lidar ratio for all of the North African sites of Table 4 is a mere 0.142 (for "pure" dust), but the correlation of the real refractive index with lidar ratio for the same sites is -0.845 .

\subsection{AERONET lidar ratios using the CALIPSO definition of dust}

Thus far, we have shown only cases where the aerosol fine volume fraction is less than 0.05 and the depolarization ratio is greater than 0.2. CALIPSO uses a depolarization ratio threshold of 0.2 to detect dust layers, but may not differentiate "pure" dust layers with very low fine mode 

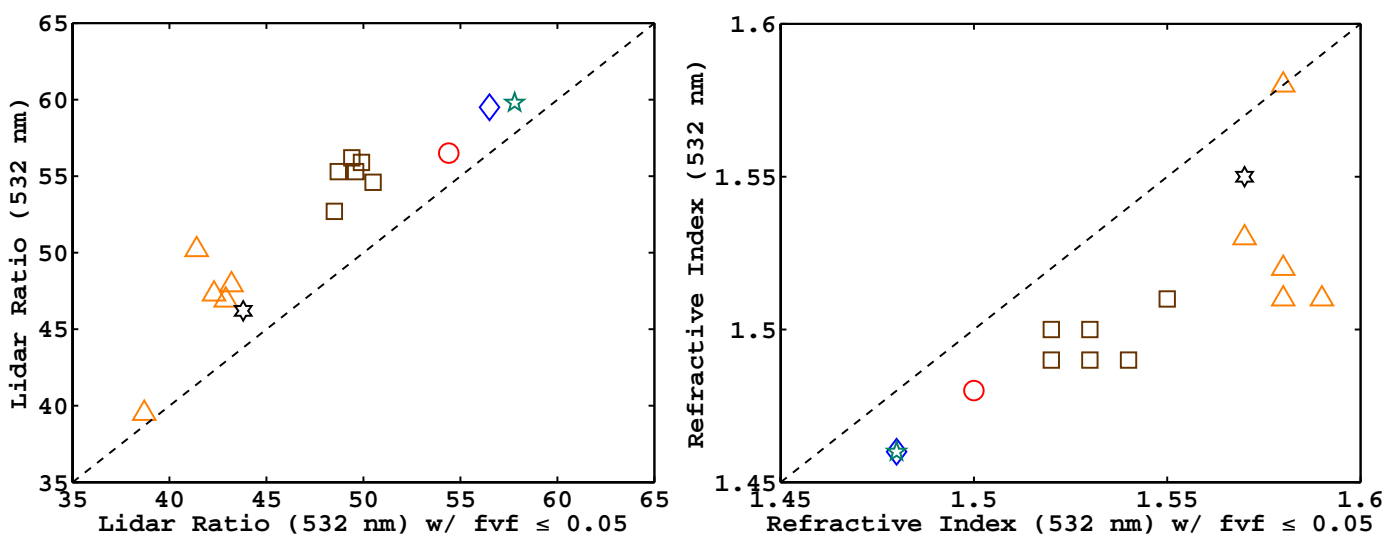

Fig. 10. Left panel: Comparison of the median lidar ratios for dust (i.e., depolarizations greater than 0.2) to the median lidar ratios for "pure" dust (fvf $\leq 0.05$ and depolarization ratio greater than 0.2 ). Right panel: Comparison of the median real refractive index for dust to the median real refractive index for "pure" dust. Note that the median lidar ratio increases when the fine mode is included, and the median real refractive index decreases when the fine mode is included. Symbol shapes correspond to the shapes in Fig. 8.

volume concentrations from dust layers with a significant fine mode volume fraction. Hence, we recompute the median lidar ratios for the 15 AERONET sites of Fig. 8, but this time we do not restrict the fine volume fraction. This screening process is not identical to the CALIPSO screening process for dust, since CALIOP measures depolarization, whereas AERONET retrieves it. However, we note that the average refractive indices obtained with the AERONET depolarization screening are nearly identical to the average refractive indices presented by Kim et al. (2011) at the same AERONET sites; Kim et al. (2011) required Angstrom exponents of less than 0.2 for their dust classification.

A comparison of the median lidar ratios for dust (i.e., depolarizations greater than 0.2 ) to the median lidar ratios for "pure" dust ( $\mathrm{fvf} \leq 0.05$ and depolarization ratio greater than 0.2 ) is shown in the left panel of Fig. 10. Note that all of the symbols in the left panel of Fig. 10 are above the 1:1 line, and that some of the median lidar ratios are substantially higher when all fine volume fractions are allowed. For instance, Table 4 indicates that $S_{532}$ increases from 41.4 to 50.2 sr at Sede Boker (located in the Middle East region) when all fine volume fractions are included, even though the median fine volume fraction only increases from 0.04 to 0.07 .

The median real refractive indices also decrease substantially when all fine volume fractions are included, as shown in the right panel of Fig. 10. This decrease in the real refractive index is probably caused by hygroscopic particles in the fine mode, which have very low real refractive indices in the high humidity conditions of summer. Since AERONET provides a single real refractive index for all particles in any given size distribution (and therefore represents an average or "effective" refractive index), the presence of hygroscopic particles reduces the retrieved real refractive index for all particle sizes, and therefore increases the lidar ratio.
The presence of hygroscopic particles in the fine mode has been documented elsewhere. Kandler et al. (2009) found significant $\mathrm{PM}_{2.5}$ mass fractions in Moroccan dust at the surface, and determined that particles less than $0.5 \mu \mathrm{m}$ diameter are dominated by ammonium sulfate. Kaufman et al. (2005) found significant fine mode fractions in MODIS retrievals over the Western African Coast during summer months, and attributed these small particles to anthropogenic pollution.

Since the fine mode particles affect the effective refractive index and lidar ratio of an aerosol layer, it is prudent to determine whether a robust relationship between fine volume fraction and lidar ratio exists. Indeed, Oo and Holz (2011) have established a relationship between MODIS estimates of fine mode fraction and the optimum lidar ratio for CALIOP analyses of maritime aerosols contaminated with anthropogenic pollution. If such a relationship exists for dust, then it might be possible to use the MODIS fine mode fraction retrievals to constrain lidar ratios for CALIPSO retrievals of dust over ocean.

We explore this relationship at the Solar Village and Capo Verde sites in Fig. 11. The Solar Village site indicates a large range of fine volume fractions and a correlation coefficient of $R=0.545$ with respect to lidar ratio. The Capo Verde site, on the other hand, displays a small range of fine volume fractions and a poor correlation coefficient $(R=$ 0.242). Thus, using MODIS fine mode fraction as a constraint may work at some locations, but not at others. The correlation coefficient for data at all of the sites listed in Table 4 with depolarizations greater than 0.2 is 0.43 . Also note the the median lidar ratio at any given fine volume fraction (black line in Fig. 11) is lower at the Solar Village site than at the Capo Verde site. This is because the real refractive indices are much higher at Solar Village than at Capo Verde for any given fine volume fraction (note color code in Fig. 11), and the real refractive index has a stronger 

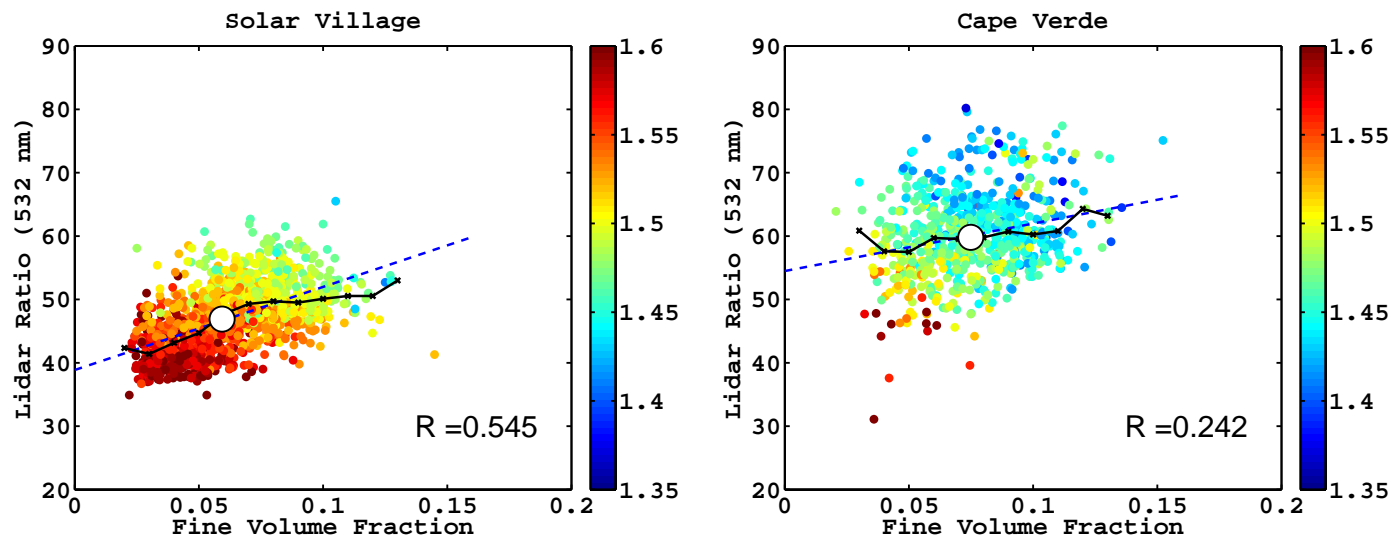

Fig. 11. AERONET-retrieved lidar ratio as a function of fine volume fraction for two dust sites; color code represents the retrieved real refractive index. Dataset is constrained to months May through September and depolarization ratios greater than 0.2. Dashed blue lines correspond to linear regressions. Solid black lines represent medians at each fine volume fraction, and the large circles represent medians of the respective datasets. Note that the Solar Village median lidar ratio is lower than the Capo Verde median lidar ratio because Solar Village dust has higher refractive indices (see colorcode).

influence on the lidar ratio than the fine volume fraction. Thus, any future retrievals using MODIS fine mode fraction as a constraint must include adjustments for regional variability. Nonetheless, Fig. 11 indicates that there is potential for constraining the lidar ratio using MODIS fine mode fractions, to the extent that MODIS fine mode fractions are related to the aerosol fine volume fraction.

Finally, Fig. 12 shows a map of median lidar ratios for all AERONET retrievals in the dust belt region with depolarizations greater than 0.2; this is similar to Fig. 8, except that we do not constrain the fine volume fraction in Fig. 12. Relaxing this constraint increases the number of AERONET sites from the 15 locations that we showed in Fig. 8 to 22 locations. Although the median lidar ratios of Fig. 12 are higher than the values shown in Fig. 8 (for reasons discussed above), the qualitative results remain the same. That is, the lowest lidar ratios occur in the Middle East (triangles), the midrange values occur in the African Sahel (squares), and the highest lidar ratios occur in non-Sahel Africa (all of the lidar ratios in Figs. 8 and 12 are tabulated in Table 4). This regional variability of the lidar ratio is mainly caused by the regional variability of the real refractive index. Since the real refractive index of dust is determined by the mineralogical composition of dust, one can equivalently state that the regional variability of the lidar ratio is caused by regional variability of the mineralogical composition of dust. We discuss this topic in the next section.

\subsection{Mineralogy of dust in the dust belt}

As shown in the previous section, the lidar ratio of dust is strongly influenced by the real refractive index of dust, which in turn is determined by the mineralogical composition of dust. Hence, we argue in this section that the regional variability of the lidar ratio shown in Fig. 12 and Table 4 is

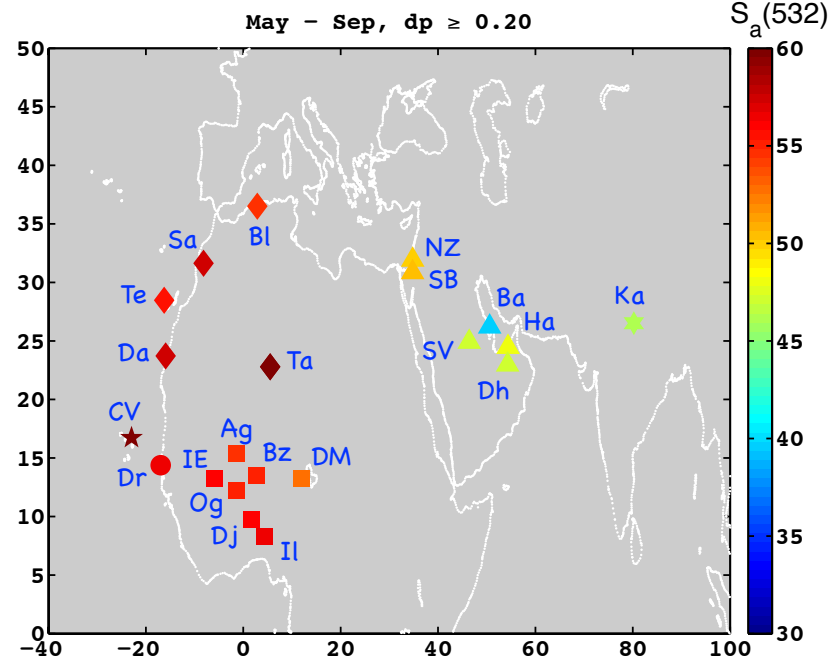

Fig. 12. Median lidar ratios for all available AERONET retrievals with depolarization ratios greater than 0.2 during the months MaySeptember.

caused by regional variability of the mineralogical composition of dust.

We begin by listing the real refractive indices of seven important minerals for modeling the radiative effect of atmospheric dust in Table 5 (Sokolik and Toon, 1999; Balkanski et al., 2007). Most of the minerals in this table are included because they constitute large mass fractions of dust aerosols in various regions of the world, but the relative concentrations of these species varies significantly from region to region. Consequently, the refractive index varies from region to region as well.

Note that illite has a much lower refractive index than the other minerals in Table 5, so the relative concentration of this 
Table 5. Refractive indices of several minerals at $532 \mathrm{~nm}$. Note that illite has a much lower refractive index than the other common dust species, so regional variability in the relative fraction of illite causes regional variability in the real refractive index of dust.

\begin{tabular}{lcl}
\hline Mineral & $n_{532}$ & Source \\
\hline Hematite & 3.18 & Chen and Cahan (1981) \\
Calcite & 1.58 & Querry et al. (1978); Ghosh (1999) \\
Quartz & 1.55 & Ghosh (1999) \\
Gypsum & 1.52 & Roush et al. (2007) \\
Montmorillonite & 1.52 & Egan and Hilgeman (1979) \\
Kaolinite & 1.49 & Egan and Hilgeman (1979) \\
Illite & 1.41 & Egan and Hilgeman (1979) \\
\hline
\end{tabular}

mineral has a significant impact on the effective refractive index of a dust layer. As we show in the discussion below, illite decreases substantially from north to south and west to east in North Africa, which causes the real refractive index to increase from north to south and west to east. This is consistent with the AERONET refractive indices shown in Fig. 8 and Table 4.

On the African continent, illite is the major clay-sized particle (i.e., less than $2 \mu \mathrm{m}$ diameter) in mineral dust aerosols originating from the Sahara, while kaolinite is the major clay in dust originating from the Sahel (Claquin et al., 1999; Lafon et al., 2006). Caquineau et al. (1998) and Caquineau et al. (2002) found that the relative proportion of illite and kaolinite collected at Cape Verde depends upon the source region of the dust. Using back trajectory analysis, they determined that dust originating in the North and West Sahara had much higher illite/kaolinite ratios $(I / K \sim 2)$ than dust that originated from South and Central Sahara $(I / K \sim 0.5)$ or from the Sahel $(I / K \sim 0.1)$. Additionally, the relative concentration of illite decreases from west to east in Northern Africa (Caquineau et al., 1998, 2002; Sokolik and Toon, 1999; Formenti et al., 2011). Indeed, Caquineau et al. (2002) compiled measurements along the Mediterranean from various studies, and found that the concentration of illite in clay minerals can be as high as $80 \%$ over the Western Mediterranean and as low as $15 \%$ over the Eastern Mediterranean (see their Fig. 8). Mineralogical analysis of the red rains in Spain indicate that the mean illite concentration ranges from 35 to $41 \%$ for dust from the Western Sahara, Moroccan Atlas, and Central Algeria regions (Avila et al., 1997), while measurements further east in Libya indicate illite fractions of only 1-6\% (O'Hara et al., 2006).

The north-south gradient of airborne dust mineralogy has also been observed in ship measurements by Chester et al. (1972) collected off of the west coast of Africa between latitudes $27^{\circ} \mathrm{N}$ and $34^{\circ} \mathrm{S}$ (March, 1971). In the Northern Hemisphere, they found that the illite clay fraction ranged from a maximum of $\sim 0.53$ at $15-20^{\circ} \mathrm{N}$ to a minimum of $\sim 0.09$ at $0-5^{\circ} \mathrm{N}$, while the kaolinite clay fraction showed an opposite trend of $\sim 0.25$ at $20-25^{\circ} \mathrm{N}$ to $\sim 0.4$ at $0-5^{\circ} \mathrm{N}$. (Montmoril- lonite was the other dominant clay that they measured, with fractions ranging from $\sim 0.12$ at $20-25^{\circ} \mathrm{N}$ to $\sim 0.43$ at 0 $5^{\circ} \mathrm{N}$ ). Behairy et al. (1975) found similar results at a lower latitude resolution (20 degrees instead of 5 degrees).

In the Middle East (Jerusalem, Israel), Kalderon-Asael et al. (2009) found low concentrations of illite for all back trajectories (less than $3 \%$ by number), and that the dust composition was usually dominated by montmorillonite, calcite, and gypsum. Ganor (1991) found large concentrations of illite $(87 \%)$ in Israel when the dust originated from the Libyan, Ahaggar-Massif, or Chad deserts in Africa, but did not find significant concentrations of illite in Israel when the dust storms originated in Saudi Arabia. Given the low concentration of illite at the local source regions in the Middle East, one would expect high refractive indices and low lidar ratios when the dust comes from local sources. This is consistent with the results shown in Fig. 8 and Table 4.

The impact of illite concentration on the refractive index of a dust mixture is easily assessed with the refractive indices of Table 5. For instance, a dust mixture with $50 \%$ illite and $50 \%$ quartz will have an approximate real refractive index of 1.48 (using volume averaging), but a mixture of $10 \%$ illite and $90 \%$ quartz has an approximate refractive index of 1.54. Thus, the AERONET refractive index climatology shown in Figs. 8 and 12 is reasonably consistent with the illite fractions of dust that are documented in the scientific literature. Hence, the lidar ratio climatology computed from the AERONET refractive indices are also consistent with the illite concentrations of the dust belt.

Hematite also has a refractive index that is much different than the other minerals (higher in this case), but iron concentrations are generally less than 3-4\% (Balkanski et al., 2007; Chou et al., 2008; Klaver et al., 2011); thus, the impact of iron oxides (both hematite and goethite) on the real refractive index is important but secondary to the bulk minerals (Lafon et al., 2006). This secondary effect enhances the north-south refractive index gradient caused by illite, since the hematite fraction increases from North to South in West Africa (Kandler et al., 2007).

Nonetheless, we would be remiss if we didn't discuss the variability of illite refractive indices found in the literature. Egan and Hilgeman (1979) used the Brewster angle optical technique to obtain a value of $n \simeq 1.41$ at visible wavelengths for compressed pellets of Fithian illite. The Egan and Hilgeman (1979) refractive indices are popular for radiative transfer calculations because they tabulate the complex refractive index throughout the $0.185-2.6 \mu \mathrm{m}$ wavelength range, and this spectral range is broad enough to accurately calculate the shortwave aerosol radiative effect (Sokolik and Toon, 1999; Balkanski et al., 2007; Klaver et al., 2011).

On the other hand, others have reported substantially higher values for the refractive index of illite. Gaudette (1965) and Friedrich et al. (2008) obtained $n=1.54-1.59$ at the single wavelength of $0.590 \mu \mathrm{m}$ for Marblehead illite and NX illite using a standard oil immersion technique for 
suspended particles. (Note that Fithian, Marblehead, and NX correspond to the various geographical source regions of the illite mixtures, and none of them are "pure" illite; Meunier and Velde, 2004). Unfortunately, the suspended particle technique has not been applied at other wavelengths. Complicating matters further, the chemical composition of illite itself varies from region to region, and can have total iron concentrations that vary from 2.2 to $9.25 \%$ (Gaudette et al., 1966). The importance of iron concentration in illite samples was demonstrated by Friedrich et al. (2008), who determined that the real refractive index of NX illite decreases substantially from 1.59 to 1.50 when the iron concentration is reduced from $6.2 \%$ to $0 \%$.

We use the Egan and Hilgeman (1979) refractive indices in our arguments because they are consistent with the AERONET real refractive index climatology over Africa and the Arabian Peninsula. It is possible that some other mineral is responsible for reducing the refractive index of mineral aggregates to a climatological value of 1.48 at Tamanrasset (for instance), but none of the other common African minerals have refractive indices this low. It is also possible that the AERONET refractive indices do not represent true climatological values for dust, and that the regional variability of the AERONET refractive indices are an artifact of irregular shapes or roughness affecting the retrieval. Spheroids (and spheres) are simplifications of the myriad of complex shapes associated with aeolian dust, after all, and the savvy reader will be interested in the ongoing discourse on this topic (Nousiainen, 2009; Merikallio et al., 2011). For instance, the spheroid particles used in the AERONET retrievals are smooth, and do not account for surface roughness effects that can alter extinction efficiency, backscattering enhancement, and depolarization ratios (Nousiainen, 2009; Redmond et al., 2010). If shape or roughness is altering the refractive index deduced by the AERONET retrieval, however, then these effects must also vary by region. Additionally, surface roughness was tested for the Dubovik et al. (2006) database, but roughness did not produce any notable improvements.

Notably, other reports of dust refractive index on the African continent fall in the 1.53-1.57 range, but these refractive indices are often obtained by computing average values based upon mineralogical composition (Kandler et al., 2009). Consequently, observations that include significant quantities of illite with $n=1.59$ will report much higher dust refractive indices than studies using a value of $n=1.41$ for illite. Other authors have analyzed concurrent size distributions, scattering, and absorption measurements using Mie theory to obtain dust refractive indices (Schladitz et al., 2009); however, the validity of using Mie theory with dust aerosols was not assessed.

\subsection{Final comments about dust}

It is interesting to note that the lidar ratios that we obtained for the dust sites are consistent with the $\tau_{\mathrm{A}}(532)$ biases ob- tained for Africa and the Middle East in Sect. 3.2. That is, the median lidar ratios for the 15 African AERONET sites in our study is 50.6 or 56.4 , depending upon whether we are considering "pure" dust or "all" dust (see the summaries at the bottom of Table 4). Since CALIPSO uses a lidar ratio of $40 \mathrm{sr}$ for dust retrievals, the relative bias with respect to the AERONET retrievals is -0.21 for pure dust (40/50.6-1) and -0.29 for all dust. These values are similar to the AOD bias of -0.20 that we found for the CALIPSO/AERONET comparisons in this region (Sect. 3.2 and Table 3). Likewise, we retrieved median lidar ratios of 42.6 for pure dust and 47.2 for all dust at the Middle East sites, so the CALIPSO lidar ratio biases are -0.06 and -0.15 in this region; the CALIPSO/AERONET AOD comparison yielded a similar bias of -0.12 . One must consider these bias comparisons with caution, however, as the sampling for the CALIPSO/AERONET AOD comparison of Sect. 3.2 is different than the sampling for the lidar ratio climatology of Sect. 4, and optical depth is not a linear function of lidar ratio.

Our results are also consistent with the work of other groups. Our median retrieved lidar ratio for dust during May through September at Capo Verde is $57.8 \mathrm{sr}$ for pure dust, and $59.8 \mathrm{sr}$ for all AERONET retrievals with depolarizations greater than 0.2 (see Table 4). This is consistent with Wandinger et al. (2010), who obtained a lidar ratio of $55 \mathrm{sr}$ from Raman lidar data at a surface site in Praia, Cape Verde, in June 2008. In particular, we obtain a median lidar ratio of $56 \mathrm{sr}$ at Capo Verde for nine days in June, 2008. Additionally, our median lidar ratio of $57.5 \mathrm{sr}$ retrieved at Saada is consistent with the value of $53-55 \mathrm{sr}( \pm 7-13 \mathrm{sr})$ determined by Tesche et al. (2009) at Ouarzazate, Morocco (located $140 \mathrm{~km}$ from Saada) for 20 days with significant dust during the Saharan Mineral Dust Experiment (SAMUM) in May-June 2006 (there are only two Level 2 AERONET retrievals during the SAMUM dust events at the Quarzazate AERONET site, though). However, the AERONET sites in Northern and Coastal Africa have higher lidar ratios than the other desert sites that we tested, (as indicated in Figs. 8, 12, and Table 4). For instance, we retrieved median lidar ratios of 42.9 and 46.9 sr for "pure" and "all" dust retrievals at Solar Village in Saudi Arabia, which is much lower than the African values. Hence, using a universal lidar ratio of 55 for all CALIPSO retrievals (as suggested by Wandinger et al., 2010) will produce positive biases of +0.28 and +0.17 at that location. This variability in the dust lidar ratio was also observed by Müller et al. (2007), who present lidar ratios of 55 and $59 \mathrm{sr}$ for Saharan dust, but indicate lidar ratios of 38 and $35 \mathrm{sr}$ for Saudi Arabia and the Gobi desert. Esselborn et al. (2009) also measured dust lidar ratios in Morocco using a high spectral resolution lidar (HSRL), and found large variability $(38-50 \mathrm{sr})$ that they attributed the dust advection from different source regions.

We emphasize that our results are specific to the AERONET sites shown in Fig. 12, and that they are not 
necessarily applicable to all conditions or locations. For instance, $97 \%$ of the "all" dust AERONET retrievals occur at $\tau_{\mathrm{A}}(440)<1.5$, and the optical properties of these retrievals do not necessarily apply to dust events with higher optical depths. Indeed, Liu et al. (2011) obtained a median effective lidar ratio (ELR) of 36 (532 nm wavelength) for opaque dust layers over Northern Africa (Sahara and Sahel), and deduced a lidar ratio of $40 \mathrm{sr}$ for thin to moderately dense African dust layers after multiple scattering effects are considered (see also Wandinger et al., 2010). Additionally, the high dust loads of $\tau_{\mathrm{A}}(532) \geq 3$ in Liu et al. (2011) correspond to very low fine volume fractions, and probably different mineralogical compositions than the AERONET retrievals of our study. Dust events tend to lift silt- and sand-sized particles into the atmosphere (i.e., particles greater than $2 \mu \mathrm{m}$ diameter), which have a different composition than clay particles (Kandler et al., 2009), but the median coarse mode effective radius at all of the AERONET sites in this study is only $1.6-2 \mu \mathrm{m}$ (see Table 4). Quartz is a major component of sand particles in West Africa, whereas illite, kaolinite, and montmorillonite are the major components of African clays (Lafon et al., 2004, 2006; Kandler et al., 2009). Kandler et al. (2009) found relative fractions of quartz to be more than 2.5 times higher during dust storm conditions in Morocco than during low-dust conditions (quartz fractions of $\sim 0.67$ vs. $\sim 0.24$ ); likewise, illite fractions are reduced from $\sim 0.27$ during lowdust conditions to $\sim 0.11$ during dust storms. This increase in quartz fraction and decrease in illite fraction results in an overall increase of the dust refractive index during dust events (recall that quartz has a relatively high refractive index and illite has a low refractive index, per Table 5). We suggest that the increase in refractive index and particle size during dust storms can have a significant effect on the lidar ratio, and that this is a possible cause of the discrepancy between the Liu et al. (2011) paper and our study.

Our results also differ from some other studies, though. Liu et al. (2008) and Omar et al. (2010) used the transmittance and two-wavelength techniques to obtain lidar ratios from CALIPSO backscatter profiles. Omar et al. (2010) also computed lidar ratios using T-matrix calculations of in situ size distributions measured during the NASA African Monsoon Multidisciplinary Analyses (NAMMA) field campaign in August 2006; they obtained relatively low lidar ratios of 35-41 for dust layers near Cape Verde. Unfortunately, there are no level 2.0 AERONET retrievals at Capo Verde on the analysis days of these papers (August 18, 19, 20, 25, and 26), and although we have computed lidar ratios smaller than 42 at Capo Verde using the AERONET retrievals, these retrievals account for only 6 of the 82 retrievals with fine volume fractions less than 0.05 at that site $(7.3 \%)$. So the low lidar ratios of Liu et al. (2008) and Omar et al. (2010) are within the range of values that we computed at Capo Verde, but they are at the extremum of our climatology.

Our results also differ from Cattrall et al. (2005), who computed a climatology for dust based upon AERONET re- trievals at four AERONET sites: Banizoumbou and Capo Verde in Africa, Bahrain and Solar Village in the Middle East. They obtained a mean lidar ratio of $42 \mathrm{sr}$ for dust with a standard deviation of $4 \mathrm{sr}$, which is much lower than the values of 47.2-57.8 sr that we summarize for all dust in Table 4 . This disparity in results is surprising, since both studies utilize some of the same AERONET sites and the same database (but over different time periods). However, we used a different method to compute lidar ratios for dust than Cattrall et al. (2005); we used the Dubovik et al. (2006) spheroid model and the optical parameters provided by AERONET to directly compute the various lidar parameters, whereas Cattrall et al. (2005) used one of the first versions of the AERONET spheroid package. This earlier spheroid package allowed two alternative inversions, spherical and spheroidal, but did not provide information about the percentage of each shape. Additionally, the range of aspect ratios used in the AERONET product was widened in 2006. Finally, Cattrall et al. (2005) did not include any constraints on the depolarization ratio or fvf for their climatology.

One item worth mentioning is that dust is located at high altitudes $(1.5-7 \mathrm{~km})$ over the Atlantic Ocean in the summer months (Prospero and Carlson, 1972; Chiapello et al., 1995, 1997; Karyampudi et al., 1999; Kaufman et al., 2005), and may be located above pollution or marine aerosols without much interstitial mixing of other aerosol species. Indeed, Ridley et al. (2012) shows seasonally averaged CALIOP extinction profiles over Africa and the Atlantic, and there is always significant extinction below the Sahran aerosol layer. AERONET is a column retrieval, however, and can not isolate dust layers from pollution or marine aerosols located above or below the dust layer. Hence, dust can not be completely isolated in the AERONET retrievals, as there are always some fine mode particles in the AERONET size distributions (for instance, note how the fine volume fraction is never zero at the Solar Village and Capo Verde AERONET sites shown in Fig. 11). Liu et al. (2008) and Omar et al. (2010), on the other hand, isolated the dust layers from the remainder of the column and are perhaps observing aerosol layers that are more "purely dust" than the typical summertime AERONET retrieval in Africa.

Kandler et al. (2009) noted that particles smaller than $0.5 \mu \mathrm{m}$ diameter collected in Morocco during SAMUM are dominated by ammonium sulfate, and therefore highly hygroscopic. These highly hygroscopic particles have very low refractive indices when hydrated, which will tend to lower the refractive index of an otherwise dusty aerosol layer (recall that AERONET assumes a single refractive index for all particle sizes, so the presence of hydrated fine mode particles will lower the retrieved refractive index of all particles). Decreasing the refractive index of aerosols in a dust layer tends to increase the lidar ratio, as shown in Fig. 9. Likewise, Masonis et al. (2003) obtained lidar ratios of 68-74 sr (at $532 \mathrm{~nm}$ ) for sub-micron sized marine aerosols (also highly hygroscopic), so these particles will also tend to raise the 
lidar ratio of an aerosol layer. Since AERONET retrievals assume a single layer for the entire atmosphere, hygroscopic fine mode particles that are located anywhere in the column can increase the retrieved lidar ratio.

\section{Conclusions}

We compared CALIPSO column aerosol optical depth (AOD) retrievals to AERONET surface measurements at 147 locations. Our analysis was restricted to cloud-free regions (as determined by both data sets) and synchronized to within $30 \mathrm{~min}$. We allowed horizontal averaging of up to $80 \mathrm{~km}$ in the CALIPSO aerosol layer product, and demonstrated that a similar bias is obtained using 20-km CALIPSO layer averages (but with a much smaller dataset). We found that sample size is more important than closest approach distance (up to $80 \mathrm{~km}$ ) for accurately determining biases of the aerosol optical depth.

Of the six CALIPSO aerosol subtypes, we found statistically significant biases at a very high confidence level for marine and dust aerosols when a single subtype was located in the column. We attribute the marine aerosol bias to the nonuniform aerosol fields that occur over oceans near the continental AERONET sites, and the fact that AERONET is consistently located closer to sources than the CALIPSO overpasses for these cases (this is not a shortcoming of either instrument). CALIPSO "dust only" aerosol retrievals produce a poor bias relative to AERONET ( $-29 \%)$, but a relatively strong correlation coefficient $(0.58)$; this may indicate that CALIPSO is correctly discriminating these aerosols as dust, but that the dust lidar ratio is too low. Additionally, the relative bias of CALIPSO with respect to AERONET at all 147 locations is $-13 \%$ globally when dust is present, and $-3 \%$ when retrievals with dust are not included in the analysis.

We also used the AERONET almucantar retrievals to compute the lidar ratio at 22 AERONET sites in the dust belt, restricting the analysis to retrievals with depolarization ratios greater than 0.2. The highest lidar ratios occur at sites in Africa that are not located on the Sahel (57.8 sr), and the lowest values occur in the Middle East for "pure" dust with fine volume fractions less than 0.05 (42.6 sr; see summaries at the bottom of Table 4). This variability in the retrieved lidar ratio is caused by the variability of the real refractive index of dust, which in turn is caused by the variability of the relative proportion of the mineral illite.

This AERONET-based lidar ratio climatology is consistent with the biases that we found in the CALIPSO/AERONET AOD comparison. That is, our AOD comparison indicates that CALIPSO is biased $20 \%$ below the AERONET AODs at the Northern African sites, and the CALIPSO lidar ratio of $40 \mathrm{sr}$ is biased $21 \%$ and $29 \%$ below the climatological values for "pure" and "all" dust that we derived in that region. Similarly, the CALIPSO AODs are biased $12 \%$ below the AERONET AODs in the Middle East region, and the CALIPSO lidar ratio is biased $6 \%$ and $15 \%$ below our climatological lidar ratios for "pure" and "all" dust. This indicates a consistency of results using two different methods.

Given the large range of valid lidar ratios for dust and the limitations of backscatter lidars, it is not possible for the CALIPSO algorithm to assess the correct lidar ratio for every dust case using a single value. Choosing any single lidar ratio for dust in the CALIPSO AOD algorithm may produce correct optical depths in some regions, but it will result in a significant bias in other regions. Multiple dust models for CALIPSO that are based upon source locations, transport times, and dust loading is one possible approach for improving the dust optical depth retrievals in the CALIPSO product.

Acknowledgements. This work was funded by NASA's Earth Science Enterprise. We appreciate the efforts of the 83 AERONET and PHOTONS (Service d'Observation from LOA/USTL/CNRS) principal investigators and the entire CALIPSO, AERONET, and PHOTONS teams for obtaining, processing, documenting, and disseminating their respective datasets. The CALIPSO data were obtained from the NASA Langley Research Center Atmospheric Science Data Center. This paper has also benefited from insightful discussions with Zhouyan Liu, Ali Omar, and Ray Rogers.

Edited by: D. Tanré

\section{References}

Anderson, T., Charlson, R., Winker, D., Ogren, J., and Holmen, K.: Mesoscale variations of tropospheric aerosols, J. Atmos. Sci., 60, 119-136, 2003.

Avila, A., Queralt-Mitjans, I., and Alarcón, M.: Mineralogical composition of African dust delivered by red rains over Northeastern Spain, J. Geophys. Res., 102, 21977-21996, 1997.

Balkanski, Y., Schulz, M., Claquin, T., and Guibert, S.: Reevaluation of Mineral aerosol radiative forcings suggests a better agreement with satellite and AERONET data, Atmos. Chem. Phys., 7, 81-95, doi:10.5194/acp-7-81-2007, 2007.

Behairy, A., Chester, R., Griffiths, A., Johnson, L., and Stoner, J.: The clay mineralogy of particulate material from some surface seawaters of the Eastern Atlantic Ocean, Mar. Geol., 18, M45M56, 1975.

Burton, S. P., Ferrare, R. A., Hostetler, C. A., Hair, J. W., Rogers, R. R., Obland, M. D., Butler, C. F., Cook, A. L., Harper, D. B., and Froyd, K. D.: Aerosol classification using airborne High Spectral Resolution Lidar measurements methodology and examples, Atmos. Meas. Tech., 5, 73-98, doi:10.5194/amt-5-73-2012, 2012.

Caquineau, S., Gaudichet, A., Gomes, L., Magonthier, M.-C., and Chatenet, B.: Saharan dust: Clay ratio as a relevant tracer to assess the origin of soil-derived aerosols, Geophys. Res. Lett., 25, 983-986, 1998.

Caquineau, S., Gaudichet, A., Gomes, L., and Legrand, M.: Mineralogy of Saharan dust transported over Northwestern tropical Atlantic Ocean in relation to source regions, J. Geophys. Res., 107, 4251, doi:10.1029/2000JD000247, 2002. 
Cattrall, C., Reagan, J., Thome, K., and Dubovik, O.: Variability of aerosol and spectral lidar and backscatter and extinction ratios of key aerosol types derived from selected Aerosol Robotic Network locations, J. Geophys. Res., 110, D10S11, doi:10.1029/2004JD005124, 2005.

Chen, C. and Cahan, B.: Visible and ultraviolet optical properties of single-crystal and polycrystalline hematite measured by spectroscopic ellipsometry, J. Opt. Soc. Am., 71, 932-934, 1981.

Chester, R., Elderfield, H., Griffin, J., Johnson, L., and Padgham, R.: Eolian dust along the eastern margins of the Atlantic Ocean, Mar. Geol., 13, 91-105, 1972.

Chew, B., Campbell, J., Reid, J., Giles, D., Welton, E., Salinas, S., and Liew, S.: Tropical cirrus cloud contamination in sun photometer data, Atmos. Environ., 45, 6724-6731, 2011.

Chiapello, I., Bergametti, G., Gomes, L., Chatenet, B., Dulac, F., Pimenta, J., and Suares, E. S.: An additional low layer transport of Sahelian and Saharan dust over the North-Eastern Tropical Atlantic, Geophys. Res. Lett., 22, 3191-3194, 1995.

Chiapello, I., Bergametti, G., Chatenet, B., Bousquet, P., Dulac, F., and Suares, E. S.: Origins of African dust transported over the Northeastern Tropical Atlantic, J. Geophys. Res., 102, 1370113709, 1997.

Chin, M., Diehl, T., Dubovik, O., Eck, T. F., Holben, B. N., Sinyuk, A., and Streets, D. G.: Light absorption by pollution, dust, and biomass burning aerosols: a global model study and evaluation with AERONET measurements, Ann. Geophys., 27, 3439-3464, doi:10.5194/angeo-27-3439-2009, 2009.

Chou, C., Formenti, P., Maille, M., Ausset, P., Helas, G., Harrison, M., and Osborne, S.: Size distribution, shape, and composition of mineral dust aerosols collected during the African Monsoon Multidisciplinary Analysis Special Observation Period 0: Dust and Biomass-Burning Experiment field campaign in Niger, January 2006, J. Geophys. Res., 113, D00C10, doi:10.1029/2008JD009897, 2008.

Claquin, T., Schulz, M., and Balkanski, Y.: Modeling mineralogy of atmospheric dust sources, J. Geophys. Res., 104, 22243-22256, 1999.

Dubovik, O. and King, M.: A flexible inversion algorithm for retrieval of aerosol optical properties from sun and sky radiance measurements, J. Geophys. Res., 105, 20673-20696, 2000.

Dubovik, O., Smirnov, A., Holben, B., King, M., Kaufman, Y., Eck, T., and Slutsker, I.: Accuracy assessments of aerosol optical properties retrieved from Aerosol Robotic Network (AERONET) sun and sky radiance measurements, J. Geophys. Res., 105, 9791-9806, 2000.

Dubovik, O., Holben, B., Lapyonok, T., Sinyuk, A., Mishchenko, M., Yang, P., and Slutsker, I.: Non-spherical aerosol retrieval method employing light scattering by spheroids, Geophys. Res. Lett., 29, 1415, doi:10.1029/2001GL014506, 2002.

Dubovik, O., Sinyuk, A., Lapyonok, T., Holben, B., Mishchenko, M., Yang, P., Eck, T., Volten, H., Munoz, O., Veihelmann, B., van der Zande, W., Leon, J.-F., Sorokin, M., and Slutsker, I.: Application of spheroid models to account for aerosol particle nonsphericity in remote sensing of desert dust, J. Geophys. Res., 111, D11208, doi:10.1029/2005JD006619, 2006.

Dubovik, O., Herman, M., Holdak, A., Lapyonok, T., Tanré, D., Deuzé, J. L., Ducos, F., Sinyuk, A., and Lopatin, A.: Statistically optimized inversion algorithm for enhanced retrieval of aerosol properties from spectral multi-angle polarimetric satellite observations, Atmos. Meas. Tech., 4, 975-1018, doi:10.5194/amt-4975-2011, 2011.

Dupont, J.-C., Haeffelin, M., Morille, Y., Noel, V., Keckhut, P., Winker, D., Comstock, J., Chervet, P., and Roblin, A.: Macrophysical and optical properties of midlatitude cirrus clouds from 4 ground-based lidars and collocated CALIOP observations, J. Geophys. Res., 115, D00H24, doi:10.1029/2009JD011943, 2010.

Egan, W. and Hilgeman, T.: Optical Properties of Inhomogeneous Materials, Academic Press, NY, USA, 246 pp., 1979.

Esselborn, M., Wirth, M., Fix, A., Weinzierl, B., Rasp, K., Tesche, M., and Petzold, A.: Spatial distribution and optical properties of Saharan dust observed by airborne high spectral resolution lidar during SAMUM 2006, Tellus B, 61, 131-143, 2009.

Formenti, P., Schütz, L., Balkanski, Y., Desboeufs, K., Ebert, M., Kandler, K., Petzold, A., Scheuvens, D., Weinbruch, S., and Zhang, D.: Recent progress in understanding physical and chemical properties of African and Asian mineral dust, Atmos. Chem. Phys., 11, 8231-8256, doi:10.5194/acp-11-8231-2011, 2011.

Friedrich, F., Steudel, A., and Weidler, P.: Change of the refractive index of illite particles by reduction of teh $\mathrm{Fe}$ content of the octahedral sheet, Clay Clay Miner., 56, 505-510, 2008.

Ganor, E.: The composition of clay minerals transported to Israel as indicators of Saharan dust emission, Atmos. Environ., 25A, 2657-2664, 1991

Gaudette, H.: Illite from Fond Du Lac county, Wisconsin, Am. Mineral., 50, 411-417, 1965.

Gaudette, H., Grim, R., and Metzger, C.: Illite: a model based on the sorption behavior of Cesium, Am. Mineral., 51, 1649-1656, 1966.

Ghosh, G.: Dispersion-equation coefficients for the refractive index and birefringence of calcite and quartz crystals, Opt. Commun., 163, 95-102, 1999.

Holben, B., Eck, T., Slutsker, I., Tanre, D., Buis, J., Setzer, A., Vermote, E., Reagan, J., Kaufman, Y., Nakajima, T., Lavenu, F., Jankowiak, I., and Smirnov, A.: AERONET - a federated instrument network and data archive for aerosol characterization, Remote Sens. Environ., 66, 1-16, 1998.

Holben, B., Tanre, D., Smirnov, A., Eck, T., Slutsker, I., Abuhassan, N., Newcomb, W., Schafer, J., Chatenet, B., Lavenu, F., Kaufman, Y., Castle, J. V., Setzer, A., Markham, B., Clark, D., Frouin, R., Halthore, R., Karneli, A., O'Neill, N., Pietras, C., Pinker, R., Voss, K., and Zibordi, G.: An emerging ground-based aerosol climatology: aerosol optical depth from AERONET, J. Geophys. Res., 106, 12067-12097, 2001.

Huang, J., Hsu, N., Tsay, S.-C., Jeong, M.-J., Holben, B., Berkoff, T., and Welton, E.: Susceptibility of aerosol optical thickness retrievals to thin cirrus contamination during the BASE-ASIA campaign, J. Geophys. Res., 116, D08214, doi:10.1029/2010JD014910, 2011.

Hunt, W., Winker, D., Vaughan, M., Powell, K., Lucker, P., and Weimer, C.: CALIPSO lidar description and performance assessment, J. Atmos. Ocean. Tech., 26, 1214-1228, 2009.

Kalashnikova, O. and Sokolik, I.: Importance of shapes and compositions of wind-blown dust particles for remote sensing at solar wavelengths, Geophys. Res. Lett., 29, 1398, doi:10.1029/2002GL014947, 2002. 
Kalderon-Asael, B., Erel, Y., Sandler, A., and Dayan, U.: Mineralogical and chemical characterization of suspended atmospheric particles over the East Mediterranean based on synoptic-scale circulation patterns, Atmos. Environ., 43, 3963-3970, 2009.

Kandler, K., Benker, N., Bundke, U., Cuevas, E., Ebert, M., Knippertz, P., Rodriguez, S., Schütz, L., and Weinbruch, S.: Chemical composition and complex refractive index of Saharan mineral dust at Izaña, Tenerife (Spain) derived by electron microscopy, Atmos. Environ., 41, 8058-8074, 2007.

Kandler, K., Schütz, L., Deutscher, C., Ebert, M., Hofmann, H., Jäckel, S., Jaenicke, R., Knippertz, P., Lieke, K., Massling, A., Petzold, A., Schladitz, A., Weinzierl, B., Wiedensohler, A., Zorn, S., and Weinbruch, S.: Size distribution, mass concentration, chemical and mineralogical composition and derived optical parameters of the boundary layer aerosol at Tinfou, Morocco, during SAMUM 2006, Tellus B, 61, 32-50, 2009.

Karyampudi, V., Palm, S., Reagen, J., Fang, H., Grant, W., Hoff, R., Moulin, C., Pierce, H., Torres, O., Browell, E., and Melfi, S.: Validation of the Saharan dust plume conceptual model using lidar, Meteosat, and ECMWF data, B. Am. Meteorol. Soc., 80, 10451075, 1999.

Kaufman, Y., Koren, I., Remer, L., Tanré, D., Ginoux, P., and Fan, S.: Dust transport and deposition observed from the TerraModerate Resolution Imaging Spectroradiometer (MODIS) spacecraft over the Atlantic Ocean, J. Geophys. Res., 110, D10S12, doi:10.1029/2003JD004436, 2005.

Kim, D., Chin, M., Yu, H., Eck, T. F., Sinyuk, A., Smirnov, A., and Holben, B. N.: Dust optical properties over North Africa and Arabian Peninsula derived from the AERONET dataset, Atmos. Chem. Phys., 11, 10733-10741, doi:10.5194/acp-1110733-2011, 2011.

Kittaka, C., Winker, D. M., Vaughan, M. A., Omar, A., and Remer, L. A.: Intercomparison of column aerosol optical depths from CALIPSO and MODIS-Aqua, Atmos. Meas. Tech., 4, 131141, doi:10.5194/amt-4-131-2011, 2011.

Klaver, A., Formenti, P., Caquineau, S., Chevaillier, S., Ausset, P., Calzolai, G., Osborne, S., Johnson, B., Harrison, M., and Dubovik, O.: Physico-chemical and optical properties of Sahelian and Saharan mineral dust: in situ measurements during the GERBILS campaign, Q. J. Roy. Meteor. Soc., 137, 1193-1210, 2011.

Koren, I., Remer, L. A., Kaufman, Y., Rudich, Y., and Martins, J.: On the twilight zone between clouds and aerosols, Geophys. Res. Lett., 34, L08805, doi:10.1029/2007GL029253, 2007.

Lafon, S., Rajot, J.-L., Alfaro, S., and Gaudichet, A.: Quantification of iron oxides in desert aerosol, Atmos. Environ., 38, 1211-1218, 2004.

Lafon, S., Sokolik, I., Rajot, J., Caquineau, S., and Gaudichet, A.: Characterization of iron oxides in mineral dust aerosols: implications for light absorption, J. Geophys. Res., 111, D21207, doi:10.1029/2005JD007016, 2006.

Liu, Z., Omar, A., Vaughan, M., Hair, J., Kittaka, C., Hu, Y., Powell, K., Trepte, C., Winker, D., Hostetler, C., Ferrare, R., and Pierce, R.: CALIPSO lidar observations of the optical properties of Saharan dust: a case study of long-range transport, J. Geophys. Res., 113, D07207, doi:10.1029/2007JD008878, 2008.

Liu, Z., Vaughan, M., Winker, D., Kittaka, C., Getzewich, B., Kuehn, R., Omar, A., Powell, K., Trepte, C., and Hostetler, C.: The CALIPSO lidar cloud and aerosol discrimination: version 2 algorithm and initial assessment of performance, J. Atmos. Ocean. Tech., 26, 1198-1213, 2009.

Liu, Z., Winker, D., Omar, A., Vaughan, M., Trepte, C., Hu, Y., Powell, K., Sun, W., and Lin, B.: Effective lidar ratios of dense dust layers over North Africa derived from the CALIOP measurements, J. Quant. Spectrosc. Ra., 112, 201-213, 2011.

Loeb, N. G. and Schuster, G. L.: An observational study of the relationship between cloud, aerosol and meteorology in broken low-level cloud conditions, J. Geophys. Res., 113, D14214, doi:10.1029/2007JD009763, 2008.

Masonis, S., Anderson, T., Covert, D., Kapustin, V., Clarke, A., Howell, S., and Moore, K.: A study of the extinction-tobackscatter ratio of marine aerosol during the shoreline environment aerosol study, J. Atmos. Ocean. Tech., 20, 1388-1402, 2003.

Mattis, I., Ansmann, A., Müller, D., Wandinger, U., and Althausen, D.: Dual-wavelength Raman lidar observations of the extinction-to-backscatter ratio of Saharan dust, Geophys. Res. Lett., 29, 1306, doi:10.1029/2002GL014721, 2002.

McGill, M., Vaughan, M., Trepte, C., Hart, W., Hlavka, D., Winker, D., and Kuehn, R.: Airborne validation of spatial properties measured by the CALIPSO lidar, J. Geophys. Res., 112, D20201, doi:10.1029/2007JD008768, 2007.

McPherson, C., Reagan, J., Schafer, J., Giles, D., Ferrare, R., Hair, J., and Hostetler, C.: AERONET, airborne HSRL, and CALIPSO aerosol retrievals compared and combined: A case study, J. Geophys. Res., 115, D00H21, doi:10.1029/2009JD012389, 2010.

Merikallio, S., Lindqvist, H., Nousiainen, T., and Kahnert, M.: Modelling light scattering by mineral dust using spheroids: assessment of applicability, Atmos. Chem. Phys., 11, 5347-5363, 2011 , http://www.atmos-chem-phys.net/11/5347/2011/.

Meunier, A. and Velde, B.: Illite, Springer-Verlag, Berlin, Germany, 2004.

Mielonen, T., Arola, A., Komppula, M., Kukkonen, J., Koskinen, J., de Leeuw, G., and Lehtinen, K.: Comparison of CALIOP level 2 aerosol subtypes to aerosol types derived from AERONET inversion data, Geophys. Res. Lett., 36, L18804, doi:10.1029/2009GL039609, 2009.

Mona, L., Amodeo, A., Pandolfi, M., and Pappalardo, G.: Saharan dust intrusions in the Mediterranean area: three years of Raman lidar measurements, J. Geophys. Res., 111, D16203, doi:10.1029/2005JD006569, 2006.

Müller, D., Ansmann, A., Mattis, I., Tesche, M., Wandinger, U., Althausen, D., and Pisani, G.: Aerosol-type-dependent lidar ratios observed with Raman lidar, J. Geophys. Res., 112, D16202, doi:10.1029/2006JD008292, 2007.

Nousiainen, T.: Optical modeling of mineral dust particles: a review, J. Quant. Spectrosc. Ra., 110, 1261-1279, 2009.

O'Hara, S., Clarke, M., and Elatrash, M.: Field measurements of desert dust deposition in Libya, Atmos. Environ., 40, 3881-3897, 2006.

Omar, A., Winker, D., Kittaka, C., Vaughan, M., Liu, Z., Hu, Y., Trepte, C., Rogers, R., Ferrare, R., Lee, K.-P., Kuehn, R., and Hostetler, C.: The CALIPSO automated aerosol classification and lidar ratio selection algorithm, J. Atmos. Ocean. Tech., 26, 1994-2014, 2009.

Omar, A., Liu, Z., Vaughan, M., Thornhill, K., Kittaka, C., Ismail, S., Hu, Y., Chen, G., Powell, K., Winker, D., Trepte, C., 
Winstead, E., and Anderson, B.: Extinction-to-backscatter ratios of Saharan dust layers derived from in situ measurements and CALIPSO overflights during NAMMA, J. Geophys. Res., 115, D24217, doi:10.1029/2010JD014223, 2010.

Oo, M. and Holz, R.: Improving the CALIOP aerosol optical depth using combined MODIS-CALIOP observations and CALIOP integrated attenuated total color ratio, J. Geophys. Res., 116, D14201, doi:10.1029/2010JD014894, 2011.

Papayannis, A., Amiridis, V., Mona, L., Tsaknakis, G., Balis, D., Bösenberg, J., Chaikovski, A., Tomasi, F. D., Grigorov, I., Mattis, I., Mitev, V., Müller, D., Nickovic, S., Pérez, C., Pietruczuk, A., Pisani, G., Ravetta, F., Rizi, V., Sicard, M., Trickl, T., Weigner, M., Gerding, M., Mamouri, R., D’Amico, G., and Pappalardo, G.: Systematic lidar observations of Saharan dust over Europe in the frame of EARLINET (2000-2002), J. Geophys. Res., 113, D10204, doi:10.1029/2007JD009028, 2008. Pappalardo, G., Wandinger, U., Mona, L., Hiebsch, A., Mattis, I., Amodeo, A., Ansmann, A., Seifert, P., Linné, H., Apituley, A., Arboledas, L. A., Balis, D., Chaikovski, A., D’Amico, G., Tomasi, F. D., Freudenthaler, V., Giannakaki, E., Giunta, A., Grigorov, I., Iarlori, M., Madonna, F., Mamouri, R.-E., Nasti, L., Papayannis, A., Pietruczuk, A., Pujadas, M., Rizi, V., Rocadenbosch, F., Russo, F., Schnell, F., Spinelli, N., Wang, X., and Wiegner, M.: EARLINET correlative measurements for CALIPSO: First intercomparison results, J. Geophys. Res., 115, D00H19, doi:10.1029/2009JD012147, 2010.

Prospero, J. and Carlson, T.: Vertical and areal distribution of Saharan dust over the Western Equatorial North Atlantic Ocean, J. Geophys. Res., 77, 5255-5265, 1972.

Prospero, J., Ginoux, P., Torres, O., Nicholson, S., and Gill, T.: Environmental characterization of global sources of atmospheric soil dust identified with the Nimbus 7 Total Ozone Mapping Spectrometer (TOMS) absorbing aerosol product, Rev. Geophys., 40, 1002, doi:10.1029/2000RG000095, 2002.

Querry, M., Osborne, G., Lies, K., Jordan, R., and Coveney Jr., R. C.: Complex refractive index of limestone in the visible and infrared, Appl. Optics, 17, 353-356, 1978.

Redemann, J., Vaughan, M., Zhang, Q., Shinozuka, Y., Russell, P., Livingston, J., Kacenelenbogen, M., and Remer, L.: The comparison of MODIS-Aqua (C5) and CALIOP (V2 \& V3) aerosol optical depth, Atmos. Chem. Phys., 12, 3025-3043, 2012, http://www.atmos-chem-phys.net/12/3025/2012/.

Redmond, H., Dial, K., and Thompson, J.: Light scattering and absorption by wind blown dust: theory, measurement, and recent data, Aeolian Research, 2, 5-26, 2010.

Repasky, K., Reagan, J., Nehrir, R., Hoffman, D., Thomas, M., Carlsten, J., Shaw, J., and Shaw, G.: Observational Studies of Atmospheric Aerosols over Bozeman, Montana, Using a Two-Color Lidar, a Water Vapor DIAL, a Solar Radiometer, and a GroundBased Nephelometer over a 24-h Period, J. Atmos. Oceanic Technol., 28, 320-336, doi:10.1175/2010JTECHA1463.1, 2011.

Ridley, D., Heald, C., and Ford, B.: North African dust export and deposition: A satellite and model perspective, J. Geophys. Res., 117, D02202, doi:10.1029/2011JD016794, 2012.

Roush, T., Esposito, F., Rossman, G., and Colangeli, L.: Estimated optical constants of gypsum in the regions of weak absorptions: application of scattering theories and comparisons to independent measurements, J. Geophys. Res., 112, E10003, doi:10.1029/2007JE002920, 2007.
Sayer, A., Smirnov, A., Hsu, N., and Holben, B.: A pure marine aerosol model, for use in remote sensing applications, J. Geophys. Res., 117, D05213, doi:10.1029/2011JD016689, 2012.

Schladitz, A., Müller, T., Kaaden, N., Massling, A., Kandler, K., Ebert, M., Weinbruch, S., Deutscher, C., and Wiedensohler, A.: In situ measurements of optical properties at Tinfou (Morocco) during the Saharan Mineral Dust Experiment SAMUM 2006, Tellus B, 61, 64-78, 2009.

Schuster, G., Dubovik, O., and Holben, B.: Angstrom exponent and bimodal aerosol size distributions, J. Geophys. Res., 111, D07207, doi:10.1029/2005JD006328, 2006.

Smirnov, A., Holben, B., Eck, T., Dubovik, O., and Slutsker, I.: Cloud screening and quality control algorithms for the AERONET database, Remote Sens. Environ., 73, 337-349, 2000.

Sokolik, I. and Toon, O.: Incorporation of mineralogical composition into models of the radiative properties of mineral aerosol from UV to IR wavelengths, J. Geophys. Res., 104, 9423-9444, 1999.

Storch, H. and Zwiers, F.: Statistical Analysis in Climate Research, Cambridge University Press, 1999.

Su, W., Schuster, G., Loeb, N., Rogers, R., Ferrare, R., Hostetler, C., Hair, J., and Obland, M.: Aerosol and cloud interaction observed from high spectral resolution lidar data, J. Geophys. Res., 113, D24202, doi:10.1029/2008JD010588, 2008.

Tesche, M., Ansmann, A., Muller, D., Althausen, D., Mattis, I., Heese, B., Freudenthaler, V., Wiegner, M., Esselborn, M., Pisani, G., and Knippertz, P.: Vertical profiling of Saharan dust with Raman lidars and airborne HSRL in Southern Morocco during SAMUM, Tellus B, 61, 144-164, 2009.

Thorsen, T., Fu, Q., and Comstock, J.: Comparison of the CALIPSO satellite and ground-based observations of cirrus clouds at the ARM TWP sites, J. Geophys. Res., 116, D21203, doi:10.1029/2011JD015970, 2011.

Vaughan, M., Winker, D., and Powell, K.: Part 2: Feature Detection and Layer Properties Algorithms. CALIOP Algorithm Theoretical Basis Document PC-SCI-202.01, 87 pp., NASA, http://www-calipso.larc.nasa.gov/resources/pdfs/ PC-SCI-202_Part2_rev1x01.pdf, 2005.

Vaughan, M., Powell, K., Kuehn, R., Young, S., Winker, D., Hostetler, C., Hunt, W., Liu, Z., McGill, M., and Getzewich, B.: Fully automated detection of cloud and aerosol layers in the CALIPSO lidar measurements, J. Atmos. Ocean. Tech., 26, 2034-2050, 2009.

Volten, H., Munoz, O., Rol, E., de Haan, J., Hovenier, J., Muinonen, K., and Nousiainen, T.: Scattering matrices of mineral aerosol particles at $441.6 \mathrm{~nm}$ and $632.8 \mathrm{~nm}$, J. Geophys. Res., 106, 17375-17401, 2001.

Wandinger, U., Tesche, M., Seifert, P., Ansmann, A., Müller, D., and Althausen, D.: Size matters: influence of multiple scattering on CALIPSO light-extinction profiling in desert dust, Geophys. Res. Lett., 37, L10801, doi:10.1029/2010GL042815, 2010.

Wiegner, M., Gasteiger, J., Kandler, K., Weinzierl, B., Rasp, K., Esselborn, M., Freudenthaler, V., Heese, B., Toledano, C., Tesche, M., and Althausen, D.: Numerical simulations of optical properties of Saharan dust aerosols with emphasis on lidar applications, Tellus B, 61, 180-194, 2009.

Winker, D., Vaughan, M., Omar, A., Hu, Y., Powell, K., Liu, Z., Hunt, W., and Young, S.: Overview of the CALIPSO mission 
and CALIOP data processing algorithm, J. Atmos. Ocean. Tech., 26, 2310-2323, 2009.

Winker, D., Pelon, J., Coakley, J., Ackerman, S., Charlson, R., Colarco, P., Flamant, P., Fu, Q., Hoff, R., Kittaka, C., Kubar, T., Treut, H. L., McCormick, M., Megie, G., Poole, L., Powell, K., Trepte, C., Vaughan, M., and Wielicki, B.: The CALIPSO Mission: a global 3D view of aerosols and clouds, B. Am. Meteor. Soc., 91, 1211-1229, 2010.

Yorks, J., Hlavka, D., Vaughann, M., McGill, M., Hart, W., Rodier, S., and Kuehn, R.: Airborne Validation of Cirrus Cloud Properties Derived from CALIPSO Lidar Measurements, Part I: Spatial Properties, J. Geophys. Res., 116, D19207, doi:10.1029/2011JD015942, 2011.
Young, S. and Vaughan, M.: The retrieval of profiles of particulate extinction from cloud-aerosol lidar infrared pathfinder satellite observations (CALIPSO) data: algorithm description, J. Atmos. Ocean. Tech., 26, 1105-1119, 2009. 